\title{
A compilation of field surveys on gaseous elemental mercury (GEM) from contrasting environmental settings in Europe, South America, South Africa and China: separating fads from facts
}

\author{
Pablo Higueras $\cdot$ Roberto Oyarzun · Joze Kotnik • José María Esbrí • \\ Alba Martínez-Coronado • Milena Horvat • Miguel Angel López-Berdonces • \\ Willians Llanos • Orlando Vaselli • Barbara Nisi • Nikolay Mashyanov • \\ Vladimir Ryzov • Zdravko Spiric • Nikolay Panichev • Rob McCrindle • \\ Xinbin Feng • Xuewu Fu • Javier Lillo · Jorge Loredo • María Eugenia García • \\ Pura Alfonso - Karla Villegas · Silvia Palacios • Jorge Oyarzún · Hugo Maturana • \\ Felicia Contreras $\cdot$ Melitón Adams $\cdot$ Sergio Ribeiro-Guevara $\cdot$ Luise Felipe Niecenski • \\ Salvatore Giammanco • Jasna Huremović
}

Received: 6 July 2013/ Accepted: 6 December 2013

(C) Springer Science+Business Media Dordrecht 2013

\begin{abstract}
Mercury is transported globally in the atmosphere mostly in gaseous elemental form $\left(\mathrm{GEM}, \mathrm{Hg}_{\text {gas }}^{0}\right)$, but still few worldwide studies taking into account different and contrasted environmental settings are available in a single publication. This work presents and discusses data from Argentina, Bolivia, Bosnia
\end{abstract}

\section{P. Higueras $(\square)$}

Departamento de Ingeniería Geológica y Minera, Escuela Universitaria Politécnica de Almadén, Universidad de Castilla-La Mancha, Plaza M. Meca 1, 13400 Almadén, Spain

e-mail: pablo.higueras@uclm.es

P. Higueras · R. Oyarzun · J. M. Esbrí ·

A. Martínez-Coronado - M. A. López-Berdonces .

S. Palacios · J. Oyarzún · H. Maturana

Instituto de Geología Aplicada (IGeA), Universidad de

Castilla-La Mancha, Plaza M. Meca 1, 13400 Almadén, Spain

\section{R. Oyarzun}

Departamento de Cristalografía y Mineralogía, Facultad de Ciencias Geológicas, Universidad Complutense, 28040 Madrid, Spain

J. Kotnik · M. Horvat

Department of Environmental Sciences, Jozef Stefan

Institute, Ljubljana, Slovenia and Herzegovina, Brazil, Chile, China, Croatia, Finland, Italy, Russia, South Africa, Spain, Slovenia and Venezuela. We classified the information in four groups: (1) mining districts where this contaminant poses or has posed a risk for human populations and/or ecosystems; (2) cities, where the concentration of

\section{W. Llanos}

Exploraciones Mineras S.A. (EM), Avenida Apoquindo 4775, Providencia, Santiago, Chile

O. Vaselli

Dipartimento di Scienze della Terra, Unversitá di

Florence, Via G. Pira, 4, 50121 Florence, Italy

B. Nisi

CNR-IGG Istituto di Geoscienze e Georisorse, Via Moruzzi 1, 56124 Pisa, Italy

N. Mashyanov · V. Ryzov

Department of Geology, St. Petersburg State University, 7/9 Universitetskaya nab., St., Petersburg 199034, Russian Federation

Z. Spiric

OIKON, Institute for Applied Ecology, Avenija

Dubrovnik 6-8, 10020 Zagreb, Croatia 
atmospheric mercury could be higher than normal due to the burning of fossil fuels and industrial activities; (3) areas with natural emissions from volcanoes; and (4) pristine areas where no anthropogenic influence was apparent. All the surveys were performed using portable LUMEX RA-915 series atomic absorption spectrometers. The results for cities fall within a low GEM concentration range that rarely exceeds $30 \mathrm{ng} \mathrm{m}^{-3}$, that is, 6.6 times lower than the restrictive ATSDR threshold (200 $\mathrm{n} \mathrm{m}^{-3}$ ) for chronic exposure to this pollutant. We also observed this behavior in the former mercury mining districts, where few data were above $200 \mathrm{ng} \mathrm{m}^{-3}$. We noted that high concentrations of GEM are localized phenomena that fade away in short distances. However, this does not imply that they do not pose a risk for those working in close proximity to the source. This is the case of the artisanal gold miners that heat the $\mathrm{Au}-\mathrm{Hg}$ amalgam to vaporize mercury. In this respect, while GEM can be truly regarded as a hazard, because of possible physical-chemical transformations into other species, it is only under these localized conditions, implying exposure to high GEM concentrations, which it becomes a direct risk for humans.

Keywords Gaseous elemental mercury ·

Atmospheric pollution · Mining districts · Cities . Pristine locations · Volcanos · Hazards · Risks

N. Panichev $\cdot$ R. McCrindle

Department of Chemistry, Tshwane University of

Technology, P.O. Box 56208, Arcadia, Pretoria 0007,

South Africa

X. Feng $\cdot$ X. Fu

State Key Laboratory of Environmental Geochemistry, Institute of Geochemistry, Chinese Academy of Sciences, Guiyang 550002, China

J. Lillo

Escuela Superior de Ciencias Experimentales y

Tecnología, Universidad Rey Juan Carlos, Tulipán s/n, 28933 Móstoles, Madrid, Spain

\section{J. Loredo}

Departamento de Explotación y Prospección de Minas, E.T.S. Ingenieros de Minas, Universidad de Oviedo, C/ Independencia 13, 33004 Oviedo, Spain

M. E. García

Facultad de Ciencias Químicas, Universidad Mayor de San Andrés, Campus de Cota-Cota, La Paz, Bolivia

\section{Introduction}

Ever since the so-called Minamata incident in Japan in 1956 (e.g., Harada 1995), when the first patient was reported as suffering from neurological symptoms, mercury has raised great fears in the international scientific community and the society. The pressure exerted on government officials has been immense and ultimately has led to restrictions on production and exports in many key countries of the world. For example, the United States of America joined the European Union in setting a date to ban their mercury exports, thereby reducing the supply of commodity mercury into the world market (Mercury Policy Project 2008). Besides, the European Union was very explicit on this matter, banning the export of metallic mercury $\left(\mathrm{Hg}^{0}\right)$, cinnabar ore $(\mathrm{HgS})$, mercury (I) chloride $\left(\mathrm{Hg}_{2} \mathrm{Cl}_{2}\right)$, mercury oxide $(\mathrm{HgO})$ and mixtures of metallic mercury with other substances, including alloys of mercury with a mercury concentration of at least $95 \%$ weight by weight (DEFRA 2010).

In particular, atmospheric mercury supposes two types of risks for human heath: (1) a direct one, related to the inhalation of gaseous mercury (at work/home), resulting in a diversity of effects on human physiology (Clarkson and Magos 2006; WHO 2000). For some examples, see: Al-Batanony et al. (2013); Aymaz et al. (2001); Bose-O'Reilly et al. (2010a, b); Echeverria et al. (1995); Gul Oz et al. (2012); Kasznia-Kocot et al. (2008); Saleem et al. (2013); Smith et al. (1970, 2013);

\section{P. Alfonso - K. Villegas - S. Palacios}

Departament d'Enginyeria Minera i Recursos Minerals, Universitat Politècnica de Catalunya, Catalunya, Spain

\section{K. Villegas}

Escuela de Postgrado, Universidad Técnica de Oruro,

Oruro, Bolivia

J. Oyarzún · H. Maturana

Departamento de Ingeniería de Minas, Universidad de la Serena, La Serena, Chile

F. Contreras · M. Adams

Facultad de Agronomía (Maracay), Universidad Central de Venezuela, Maracay, Venezuela

S. Ribeiro-Guevara

Centro Atomico, Bariloche, Argentina

L. F. Niecenski

Universidade Federal do Rio Grande, Porto Alegre, Brazil 
Yuen et al. (2000); and (2) collateral risks, related to changes in mercury species, for example, gaseous elemental mercury (GEM) into reactive gaseous mercury (RGM), or RGM into methylmercury (increasing health risks; Lindqvist and Rodhe 1985; Holmes et al. 2010; Lin and Pehkonen 1999; Bernhoft 2012; Chan and Egeland 2004; Grandjean et al. 2010, among many others). This is the reason why international programs for atmospheric mercury monitoring have been promoted worldwide (Fu et al. 2012; Pacyna et al. 2010; Pirrone et al. 2013; Selin et al. 2007; Sprovieri et al. 2010).

In order to provide information on this global pollutant from contrasted environmental settings, we present a compilation of field data on atmospheric mercury (GEM) from 27 different sampling sites located in Europe, South America, South Africa and China (Fig. 1). Our surveys were carried out using portable LUMEX RA-915 series atomic absorption spectrometers, property of the different institutes or universities involved in this study. As the instrument is calibrated by the same device and the calibration verified by the producer, the measurement results in all these different sites is traceable to the same source and can be regarded as comparable. Also to note is that our measurements were carried out covering a long time span, with the first surveys carried out in 1995, and the last ones in 2012.

We also discuss the potential sources of this pollutant and whether GEM may pose (or not) a risk to human health in the different studied localities.

\section{Materials and methods}

Our field surveys for GEM were carried out by car, on foot or at fixed locations, during different time intervals in mining districts, cities, or pristine locations from Argentine, Bolivia, Bosnia and Herzegovina, Brazil, Chile, China, Croatia, Finland, Italy, Russia, South Africa, Spain, Slovenia and Venezuela (Fig. 1). In most cases, the equipment measured and registered one GEM concentration every second, but in others we used

\section{S. Giammanco}

Instituto Nazionale di Geofisica e Volcanologia, Catania, Italy

\section{J. Huremović}

Prirodno matematicki fakultet, Sarajevo, Bosna and Herzegovina integrating times over one second: in this case, the device gives the average concentration for the integration time.

Table 1 shows general information about the surveys. Background (reference) levels were established on the basis of surveys carried out in areas without known $\mathrm{Hg}$ pollution, or, for polluted areas, using transects away from the main $\mathrm{Hg}$ sources. Given the variability of GEM concentrations, we decided to test the type of statistical distribution that would best fit the data sets to avoid ulterior distortions. The Gaussian or normal distribution is assumed to describe the random variation that occurs in a data set. However, many distributions show important skewness, which disappears if we deal with the logarithm of the values $(\log \mathrm{x})$. This behavior is typical of trace elements, where a few high concentration data distort a distribution characterized by low concentrations. Thus, if $\log x$ distributes normally, we say that this distribution is log-normal (e.g., Limpert et al. 2001). In this regard, after testing data distribution, the normal distribution proved to have a strong skewness, and therefore, our data were log-transformed, which better fitted the Gaussian bellshaped pattern. This allowed us to calculate the geometric mean and to produce histograms for quick visualization of distribution data (Figs. 2, 3).

The instrument of choice for the surveys was the widely used LUMEX RA-915, which has proved to be very reliable for GEM studies, having been used in a large number of surveys worldwide; for example, a few studies (among many) conducted during the last decade include those of Palinkas et al. (1990), Sholupov et al. (2004), Higueras et al. (2005, 2006, 2012, 2013), Kotnik et al. (2005), Kim et al. (2006), García-Sánchez et al. (2006a, b), Aiuppa et al. (2007), Almeida et al. (2008), Llanos et al. (2010), Fu et al. (2011), Martínez-Coronado et al. (2011), Kocman et al. (2011), Yasutake et al. (2011) and Vaselli et al. (2013). The LUMEX RA-915 series analyzers for continuous GEM measurements (models RA-915+ and $915 \mathrm{M}$ ) are portable multifunctional atomic absorption spectrometers, with Zeeman background correction, which eliminates the effect of interfering impurities (Sholupov and Ganeyev 1995). These are high sensitivity and selectivity instruments that do not require gold amalgam preconcentration and subsequent regeneration steps. This enables the user to conduct real-time monitoring. The quality and performance of the LUMEX RA-915 instrument have been verified at the Advanced Monitoring Systems Center 
(USA) during test works commissioned by the US EPA (2001). The analytical procedure is based on Zeeman atomic absorption spectrometry with highfrequency modulation of light polarization (ZAASHFM; Sholupov and Ganeyev 1995; Sholupov et al. 2004). Application of Zeeman background correction and a multipath analytical cell provides high selectivity and sensitivity of measurements. The instrument allows determination of $\mathrm{Hg}$ in air directly with an ultra low detection limit in real time. All air measurements were fulfilled in accordance with the European standard CSN EN 15852 (European Standards 2013), developed by the Working Group 25 of the European Committee for Standardisation's (CEN) Technical Committee 264 "Air Quality" (Brown et al. 2010a, b).

Operation of the instrument can be tested using inbuilt test cell with known $\mathrm{Hg}$ vapor concentration at certain temperature. The producer suggests that if the relative deviation of the measured values from table value is below $20 \%$, the analyzer is ready to use (LUMEX RA-915+ User manual 2001). FernándezPatier and Ramos-Díaz (2012) carried out an intercomparison exercise with Lumex RA-915M and Tekran 2537B equipments belonging to Spanish institutions IGeA-UCLM and "Instituto de Salud Carlos III". The results yielded a compatibility index (after ISO/IEC Guide 43-1, 1997) below 1 during all the experiments. Lumex air mercury measurements also comply with the UE standard method to measure total gaseous mercury (EN 15852, 2010).

The LUMEX RA-915 dynamic range covers four orders of magnitude $\left(2-30,000 \mathrm{ng} \mathrm{m}^{-3}\right)$ with response time of $1 \mathrm{~s}$, although we also taken into account the readings below $2 \mathrm{ng} \mathrm{m}^{-3}$ since these are also acceptable by the required data quality objectives of the Fourth Air Quality Daughter Directive (Brown et al. 2010a, b). Although from a strict analytical point of view, these figures may be a bit less reliable, and they nonetheless reflect the existence of very low concentrations of GEM; hence, it would have been unwise to discard such valuable information. For a complete description of the method and instrumentation, see Sholupov et al. (2004).

\section{Results and discussion}

The surveys

We have divided our sampled areas in four groups (Fig. 1): (1) areas in which the mining of alluvial gold using mercury for amalgamation, or mercury extraction from cinnabar, poses or has posed a potential risk

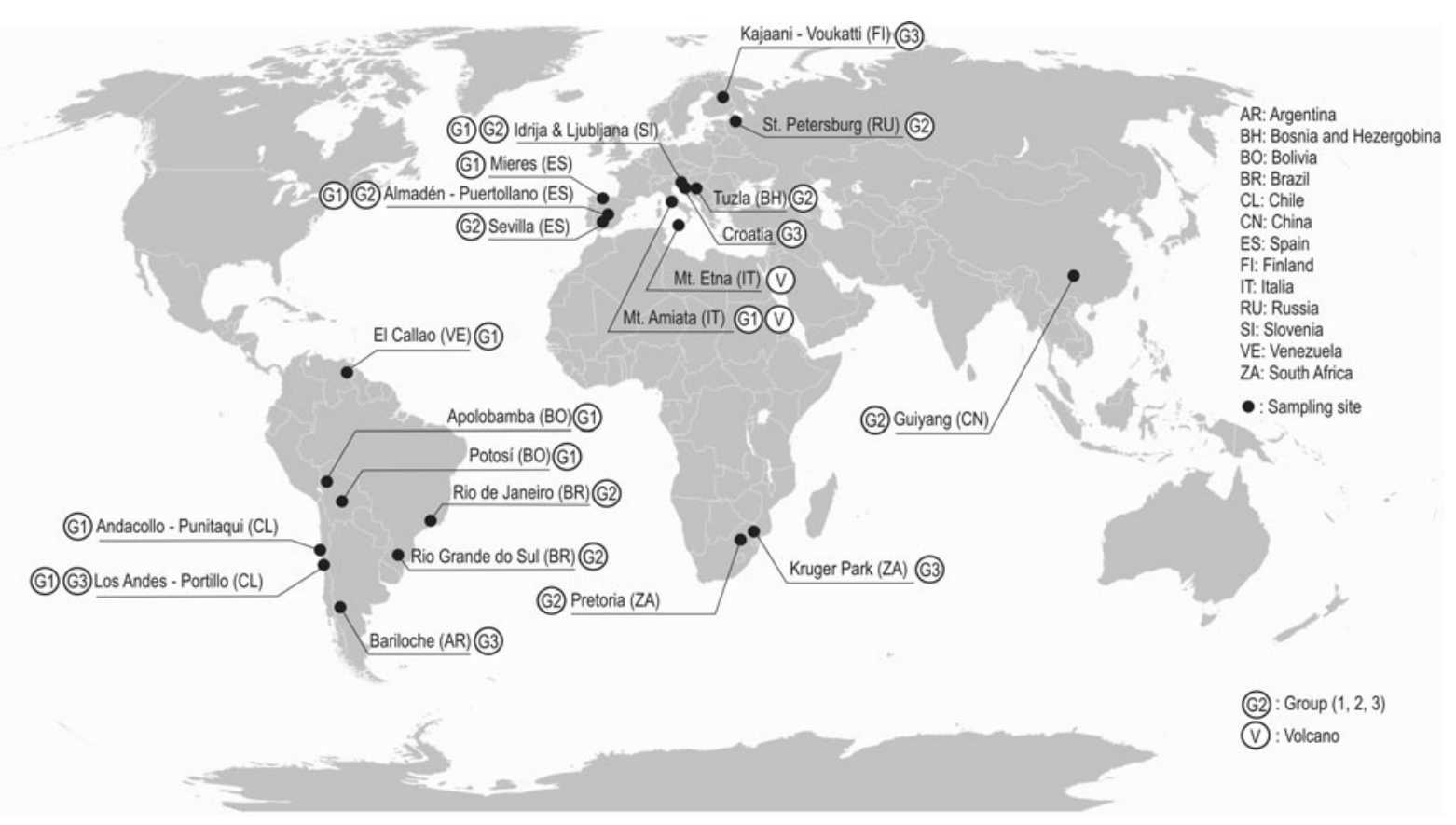

Fig. 1 Sampling sites indicating the group (G1-3) they belong to: 1 mining districts; 2 cities; and 3 pristine areas 


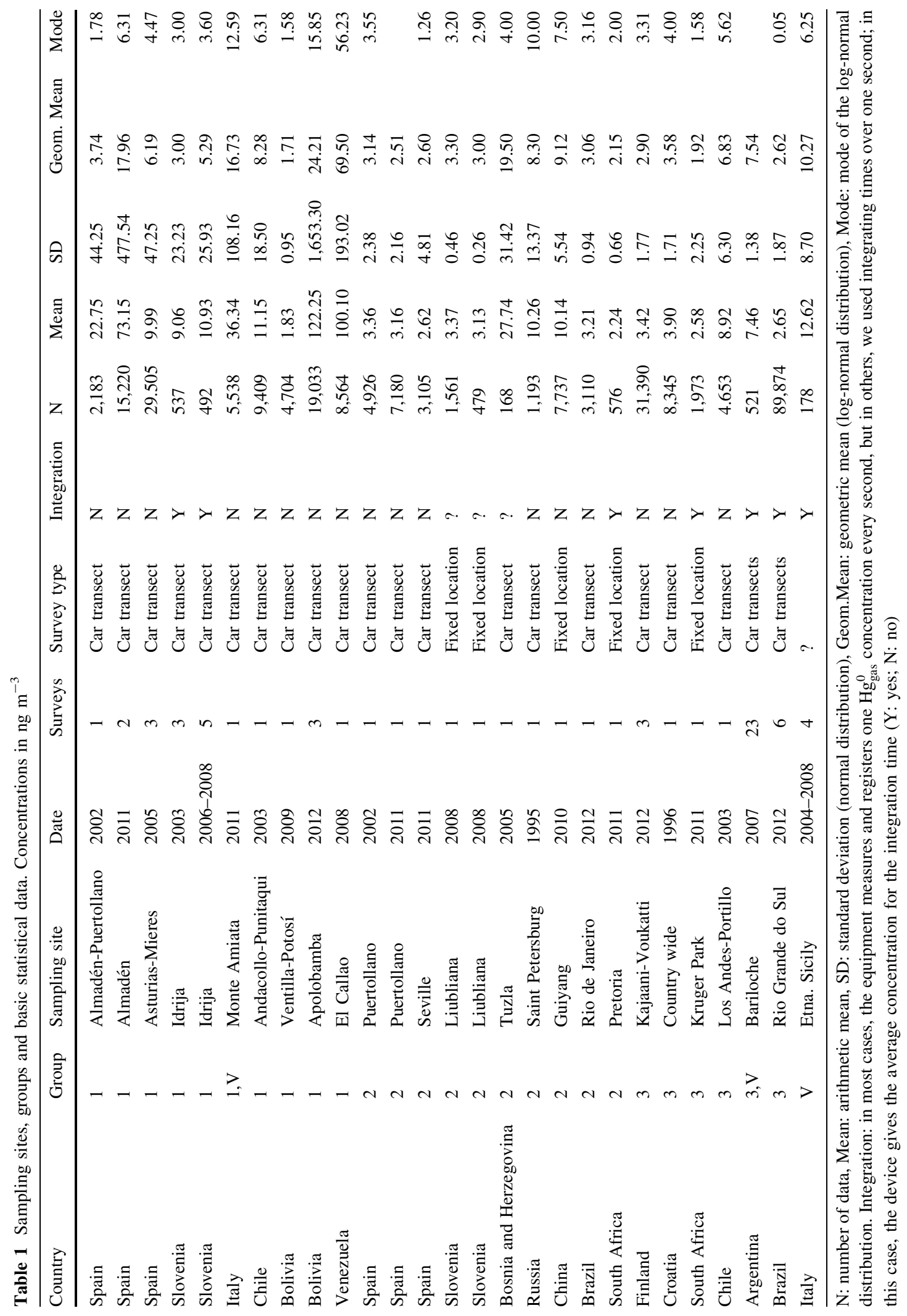



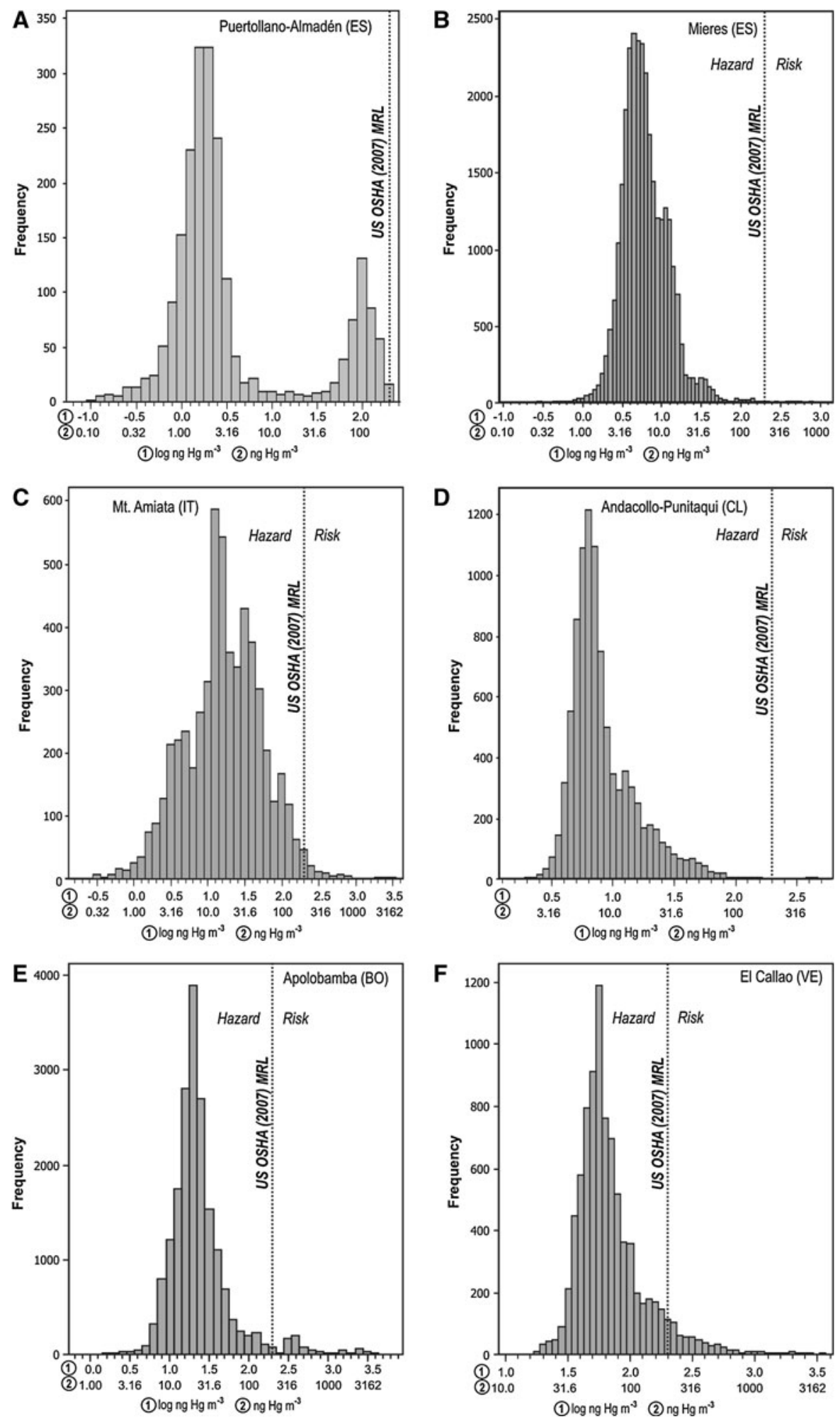

Fig. 2 Log-normal distribution of GEM concentration in selected localities belonging to Group 1. Minimum risk level (MRL) for chronic inhalation of GEM at $200 \mathrm{ng} \mathrm{m}^{-3}$ (US OSHA, 2007) 
for human populations and/or the environment; (2) cities, where the concentration of atmospheric mercury could be higher than normal due to (for example) to the burning of fossil fuels; (3) volcanic areas, where mercury emissions are mostly of natural origin; and (4) pristine areas where no anthropogenic influence is apparent.

\section{Mining areas}

We shall start with Group 1 and the transect $(78 \mathrm{~km})$ Almadén-Puertollano (Spain; Figs. 1, 2a), which was carried out in February 2002, when the metallurgical plant of Almadén was still operating. Almadén was, until the closure (2003) of the mines and the metallurgical plant, the largest producer of mercury worldwide. The mining district hosts the world's largest cinnabar mine (Almadén) and five other smaller mines that were active at different historical periods. In this respect, the whole district area can be regarded as the world's largest mercury geochemical anomaly, not only because of its millennial mining history but also due to the widespread presence of the element in the area (Gray et al. 2004; Higueras et al. 2006). The polluted environmental setting is completed with the existence of waste dumps materials that were traditionally used throughout history to mend local roads and tracks, thus contributing to the dispersion of the element in the area (e.g., Martínez-Coronado et al. 2011). On the other hand, the highly industrialized city of Puertollano is $65 \mathrm{~km}$ away from Almadén and hosts two coal-fired thermoelectric plants and a huge oil refinery. In more than a way, Puertollano has a notoriously polluted atmosphere (e.g., Moreno et al. 2006), and given that mercury is emitted from coal combustion plants (e.g., Carpi 1997) and oil refineries (e.g., O'Rourke and Connolly 2003), and it was interesting to investigate what a transect between two polluted sites might reveal. The results (Fig. 2a) show a typical bimodal behavior, with a background population in the order of a few $\mathrm{ng} \mathrm{m}^{-3}$ and an anomalous one in the order of a few hundred $\mathrm{ng} \mathrm{m}^{-3}$. The latter correspond to these areas where the influence of the metallurgical plant of Almadén is evident. Conversely, as shown by the Almadén-Puertollano transect and specific measurements carried out at the city of Puertollano (see also discussion on Group 2), the area has very low GEM concentrations, in the order of a few ng $\mathrm{m}^{-3}$ (Fig. 3a). This defies preconceptions regarding combustion plants and mercury emissions (e.g., Carpi 1997; O'Rourke and Connolly 2003) and call for a reassessment of potential risks regarding this matter.

The Asturias-Mieres (Spain; Figs. 1, 2b) survey was also puzzling as we expected substantially "larger than normal" concentrations of GEM. The studied area in northern Spain hosts two large potential sources of mercury emissions: (1) two coal-fired plants and (2) an abandoned cinnabar mining district comprising a few small mines, being the most important ones those of Terronal-La Peña in Mieres and Soterraña in Pola de Lena (Loredo et al. 1999). The survey was carried out in 2005 around Mieres and passed through the proximity of the already mentioned coal plants and mines. As shown by the graphic (Fig. 2b), the concentrations form a large log-normal population in the range of a few to tens $\mathrm{ng} \mathrm{m}^{-3}$ and a very small one in the order of a few hundred $\mathrm{ng} \mathrm{m}^{-3}$. Thus, it seems that neither the mines nor the combustion plants exert a strong influence on what GEM concentrations are concerned.

In Idrija (Slovenia), second biggest world mercury deposits were discovered more than five centuries ago. Since then until 1995, the area experienced extensive mining and cinnabar smelting history, which resulted in severe $\mathrm{Hg}$ contamination of local environment. After the mine and smelter closure, $\mathrm{Hg}$ concentrations in air have been monitored at several locations across Idrija area as well in its influence area down flow Idrijca and Soča rivers that continuously erode big amounts of contaminated material into the Gulf of Trieste (Žagar et al. 2006; Kocman et al. 2011). Nowadays in Idrija, main anthropogenic sources are still active mine ventilation shafts (Inzaghi, Pravica, Cegovnica), evaporation from heavily polluted former smelting plant area, chimney area, rock dumps of exploited ore and ore residues treated in various ways. In Pront area, an outcrop of mercury ore (native $\mathrm{Hg}$ ) is the main natural source of atmospheric mercury, due to evaporation of elemental $\mathrm{Hg}$ from soil and base rock, as well as in Idrijca River it is due to erosion of soils with elevated $\mathrm{Hg}$ concentrations. Detailed car mapping of Idrija area was performed during different seasons in 1994 (Gosar et al. 1997), 2003 (Kotnik et al. 2005) and in 2006 (Kocman et al. 2011). Air Hg measurements were also regularly performed, at fixed locations, in certain most polluted and populated places such as ventilation shafts, former smelting and 

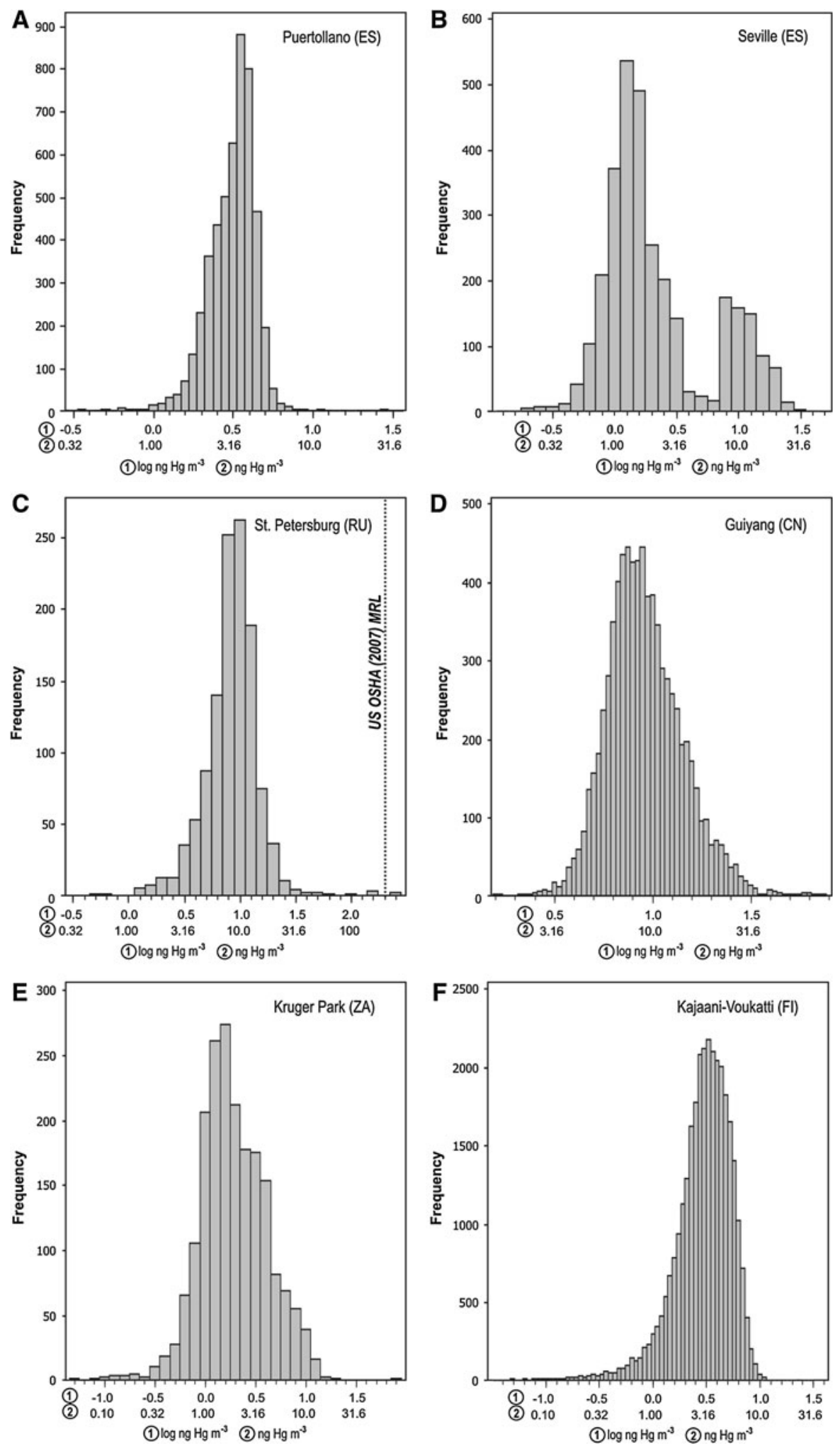
4Fig. 3 Log-normal distribution of GEM concentration in selected localities belonging to Groups 2 (a-d) and 3 (e, f). Minimum risk level (MRL) for chronic inhalation of GEM at $200 \mathrm{ng} \mathrm{m}^{-3}$ (US OSHA, 2007)

chimney area, main town squares and ore outcrop in Pront, for last 12 years, either within regular monitoring program or other research activities. In Idrija town, during last 17 years after last smelting operation, $\mathrm{Hg}$ concentration in air decreased rapidly from more than $1,000 \mathrm{ng} \mathrm{m}^{-3}$ to few $\mathrm{ng} \mathrm{m}^{-3}$ (measured in fall 2012 around the town). There are some locations around ventilation shafts, natural outcrop of $\mathrm{Hg}$ ore, and ore and smelting residue dumps where $\mathrm{Hg}$ in air still remains high $\left(10-15 \mathrm{ng} \mathrm{m}^{-3}\right.$ in fall 2012). Besides, $\mathrm{Hg}$ levels remain high around former smelting plant $\left(\sim 1,000-2,000 \mathrm{ng} \mathrm{m}^{-3}\right)$ and chimney area, where concentrations of few tens of $\mu \mathrm{g} \mathrm{m}^{-3}$ were measured (summer 2012). Distribution and $\mathrm{Hg}$ concentrations in air over the town of Idrija strongly depend on weather and wind conditions as during cold and windy weather, low concentrations were measured even at locations around former smelting facility, while hot and sunny weather promotes $\mathrm{Hg}$ evaporation from contaminated areas and thus locally increase air concentrations.

In Italy (Tuscany), we surveyed the Monte (Mt.) Amiata region (Figs. 1, 2c). For a complete description of the site, see for example Loppi (2001) and Morteani et al. (2011). Mt. Amiata was the third largest mining district in $\mathrm{Hg}$ production and at present (as the rest of the European $\mathrm{Hg}$ mines) is closed. The Mt. Amiata volcano is the youngest and largest volcanic edifice in Tuscany (central-northern Italy) and is characterized by a geothermal field, exploited for the production of electrical energy. In the past, Mt. Amiata was also known as a world-class $\mathrm{Hg}$ district whose mining activity was mainly distributed in the central-eastern part of the volcanic complex, particularly in the township of Abbadia San Salvatore. The surveys for GEM were carried out by car (for longdistance regional surveys) and on foot (for local-scale measurements; Vaselli et al. 2013). No reclamation measures had been carried out in the area before the surveys, which implies that the relicts of the mining and metallurgical activities were still emitting GEM to the atmosphere. Our transect for GEM was done between the relatively large Siele and Morone mines, which are located some $10 \mathrm{~km}$ southward of Abbadia San Salvatore. As one may expect, the area of Mt.
Amiata has large concentrations of GEM. There are several reasons for the existence of these large figures of up to thousands $\mathrm{ng} \mathrm{m}^{-3}$ : (1) abandoned $\mathrm{Hg}$ mines and mineral dumps; (2) abandoned calcine dumps; (3) on-going Hg-rich volcanic-geothermal activity; and last but not least (4) a geothermal plant that operates with Hg-rich vapors. Thus, the existence of high concentrations exceeding $1,000 \mathrm{ng} \mathrm{m}^{-3}$ should not surprise anyone. Conversely, what is really odd is that these figures are rare in the data set, and not even the concentrations above $100 \mathrm{ng} \mathrm{m}^{-3}$ are particularly common. In fact, the log-normal distribution has a mode of a mere $12.6 \mathrm{ng} \mathrm{m}^{-3}$; this poses serious doubts on actual extent and impact of the GEM anomalies around hot spots of mercury concentration, something which we already came across in the Almadén District (e.g., Llanos et al. 2010; Martínez-Coronado et al. 2011; Higueras et al. 2013). Mercury gas may be a global pollutant, but strong dilution in the atmosphere makes its impact (at high concentration levels) extremely local.

The Andacollo-Punitaqui (Chile; Figs. 1, 2d) transect $(89 \mathrm{~km})$ was carried out in 2003 between two mining districts that hosts mercury deposits (Higueras et al. 2004, 2005). Andacollo has been a site of continuous use of mercury for gold recovery for centuries. Hard rock mining was introduced before the end of the sixteenth century, and the main technological innovation consisted in the introduction of the water powered "trapiches" (an old Spanish word for mill), rock crushers consisting in two massive grinding stones mounted vertically on a horizontal axle and turning on top of a circular stone. An improved version of the old trapiches is used at present by the smallscale mining operations that still exist in the district (Fig. 4). The trapiches are used for two purposes: (1) to crush ore for flotation of copper sulfides and (2) to recover gold on copper plates, which are covered by a thin film of mercury. The operation requires $0.8 \mathrm{~kg}$ $\mathrm{Hg}$ /day, and only $50-70 \%$ of this mercury is later recovered. On the other hand, the Punitaqui district comprises shear-related copper-gold, and mercuryvein type deposits, and neither mining of mercury nor gold recovery using this element is performed at present. Taking all this into consideration, the survey was expected to result in the reading of high concentrations levels of GEM. However, apart from a few truly high concentrations found at the Andacollo and Punitaqui sites, ranging from hundreds to thousands of 
ng $\mathrm{m}^{-3}$ (Higueras et al. 2004, 2005), the rural area between the districts has a mode of $6.3 \mathrm{ng} \mathrm{m}^{-3}$. This should not come as a surprise, because even within the Andacollo district, the figures may vary from a few $\mathrm{ng} \mathrm{m}^{-3}$ up to thousands. For example, the Dayton $\mathrm{Au}$ ) open pit does not show high levels of mercury, except for a few data from the Natalia pit in the order of 20-30 $\mathrm{ng} \mathrm{m}^{-3}$. The higher levels are to be found in the town itself, at the entrance of the giant cyanide heap-leaching operation of Dayton, and particularly near to the trapiches. The same applies to Punitaqui, where we detected highly variable levels of mercury that result in three data populations: (1) very low concentrations (up to $2 \mathrm{ng} \mathrm{m}^{-3}$ ) that represent clean agricultural areas; (2) a transitional population between 2 and $12 \mathrm{ng} \mathrm{m}^{-3}$ detected in the immediate vicinity of the mining complex; and (3) a truly anomalous population that reach values well over $100 \mathrm{ng} \mathrm{m}^{-3}$ (Higueras et al. 2005). Thus, the Andacollo-Punitaqui case further supports a weak to extremely weak dispersion of GEM, which must become strongly diluted in the atmosphere after it leaves the source and mixes with clean air (Fig. 2d).

The Apolobamba area in Bolivia (Figs. 1, 2e) is located about $160 \mathrm{~km}$ to the NNW of La Paz, and it is one of the main sites for artisanal gold mining (AGM) at present in Bolivia. The gold mines are relatively scarce (4-5 in activity during our visit), and they are relatively irrelevant in terms of production and have one or two milling facilities per mining site. During the survey, we also visited the "country market" where the gold trade is carried out and where the sellers "reburn" the $\mathrm{Au}-\mathrm{Hg}$ amalgam to purify the gold. The rest of the region is almost pristine, with very low population, and it is located at an altitude of 2,500-5,100 m a.s.1. However, Acosta et al. (2011) indicate that mining produces a very serious impact on the ecosystems as well as on the health of miners and inhabitants. In this regard, there is common misconception regarding the chemistry of mercury, because different from what is rather usually sustained by the extreme views held by some lobbying environmental groups, a drop of metallic mercury will not dissolve instantly in water like table salt. In fact, even at laboratory conditions, metallic mercury is only slightly soluble in water (e.g., WHO 2005; Health Canada 2009). Our data set shows a slightly bimodal population (Fig. 2e) with a low main mode of $16 \mathrm{ng} \mathrm{m}^{-3}$. Similar to the Chilean case, we found that at Apolobamba, most of the data are at low levels, which increase to hundreds and even thousands of $\mathrm{ng} \mathrm{m}^{-3}$ (Fig. 2e) at localized pollution hot spots related to the use of mercury for amalgamation.

The Venezuelan data (Figs. 1, 2f) were obtained during a survey carried out at the El Callao area (SE Venezuela) during July 2008. This area hosts an important number of small-scale mining sites, as well as an important mine operated by the state-owned company MINERVEN, which has two cyanidation plants producing together about $200-300 \mathrm{~kg}$ of gold/ month (Veiga et al. 2005). The town (El Callao) is also an important jewelry center, with gold trade involving the re-burning of amalgams to purify the gold; no data from El Callao town were used in our survey. The Minerven's Peru Plant processes 5,200 tons of material per month, and about $15 \%$ of the material are $\mathrm{Hg}$ contaminated tailings purchased by the company from the artisanal gold miners (Veiga et al. 2005). In turn, the artisanal miners use copper plates usually dressed with a thin layer of mercury used to amalgamate free gold particles (Veiga et al. 2005), a procedure equivalent to that employed at Andacollo (Chile; see Higueras et al. 2004, 2005; Fig. 4). Abrasion of the mercury surface releases droplets that go out with the pulp, and given that the majority of artisanal miners in El Callao do not use a mercury trap at the end of the plates, the tailings usually contain between 60 and $80 \mu \mathrm{g} \mathrm{g}^{-1}$ (Veiga et al. 2005). The results of our survey resemble those of Apolobamba (Bolivia) although the mode is higher at $56 \mathrm{ng} \mathrm{m}^{-3}$. Besides,

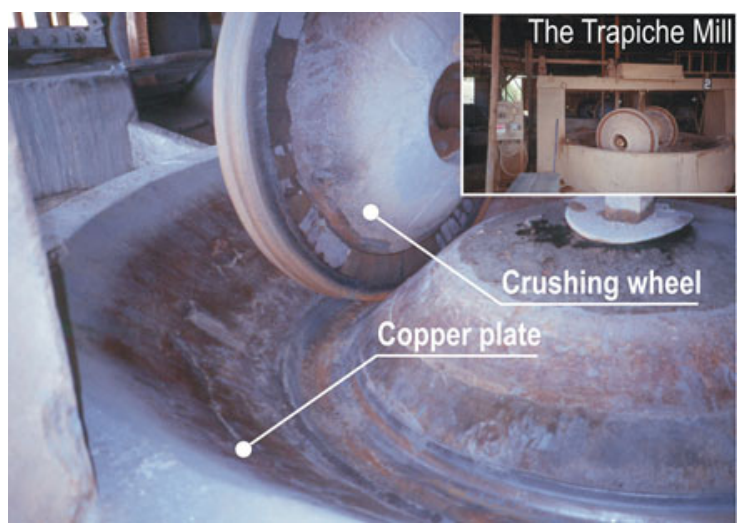

Fig. 4 A "trapiche" mill in Andacollo with its copper plate for gold recovery on a thin film of mercury (Chile). These enclosed sites may reach GEM concentrations in order of $10^{3}-10^{4} \mathrm{ng} \mathrm{m}^{-3}$ (Higueras et al. 2004, 2005) 
if we compare the modes obtained for artisanal gold mining (AGM) in our South American case studies (Table 1), a pattern emerges from a mere $6.3 \mathrm{ng} \mathrm{m}^{-3}$ at Andacollo (Chile) to $16 \mathrm{ng} \mathrm{m}^{-3}$ at Apolobamba (Bolivia) and $56 \mathrm{ng} \mathrm{m}^{-3}$ at El Callao (Venezuela). Given that procedures for gold recovery are similar in these districts, this remarkable increase can only be explained in terms of processed tonnage, which is much larger at El Callao, whereas at Andacollo, AGM is just a slowly dying relict activity. Additionally, perhaps we should highlight another fact: the GEM concentration levels from El Callao are equivalent or higher than those highly polluted mercury districts such as Almadén, Idrija and even Mt. Amiata (Table 1). This is important enough to call the attention on a site that is not only overwhelmed by poverty but also by the dangers imposed by outdated and risky procedures for gold recovery (see Veiga et al. 2005).

\section{Cities}

Regarding Group 2 (Cities), we have already discussed that the case of Puertollano (Spain), which despite being a highly industrialized city hosting coalfired plants and a large oil refinery, has low concentrations of GEM (Fig. 3a). Seville (Spain; Figs. 1, 3b) is the fourth largest city in Spain and has a population of about 700,000 inhabitants. The township covers an area of about $140 \mathrm{~km}^{2}$, whereas the metropolitan area comprises 46 towns with a total population of about $1,500,000$ inhabitants. Seville is an important commercial, services and financial center, and the metropolitan area hosts an important industrial activity. Our survey was carried out in 2011 and resulted in a peculiar bimodal data distribution. However, both the background and the anomalous populations display low and very low GEM concentration data. The first one mostly consists of $0.3-3 \mathrm{ng} \mathrm{m}^{-3}$ data, which is low indeed for a large city. The second population whose origin is uncertain should not be considered as an environmental potential risk, because the largest figures are below $30 \mathrm{ng} \mathrm{m}^{-3}$. Thus, we have two urban cases where despite the existence of potential sources of mercury emissions such as oil refineries, coal-fired power plants (Puertollano) and intensive traffic and industry (Seville), the figures for GEM concentration are very low. On the other hand, Rossini Oliva and Fernández Espinosa (2007) indicate that the industrial influence in Seville is of lesser importance, and that the main anthropogenic emissions are related the vehicular traffic. Thus, the key question here is how fuel combustion actually relates to mercury emissions. In this regard, Pacyna et al. (2006) indicate that "as much as two-thirds of the total emission of ca, 2,190 tones of $\mathrm{Hg}$ emitted from all anthropogenic sources worldwide in 2000 came from combustion of fossil fuels." This is intriguing, because as shown by our data, neither traffic nor combustion of coal seems to have a severe impact on what concentration of GEM is concerned. Thus, either there is an overestimation regarding the data scaling process for the global emissions, or GEM dissipates from the urban environment too fast to be measured accurately. Whatever the case might be, having relatively low concentrations of GEM at air-polluted cities such as at Puertollano or Seville is a remarkable fact and good news for the inhabitants of these cities and others listed in Table 1. On the other hand, Slemr et al. (2011) suggest that the mercury emissions reductions in some countries are believed to be offset or even surpassed by the increasing emissions in rapidly industrializing countries. However, perhaps we are too strongly focusing our approach to mercury emissions on anthropogenic sources, either forgetting or inadvertently bypassing the existence of others of (also) major importance. In this respect, naturally, $\mathrm{Hg}$-enriched substrates constitute long-lived sources of mercury to the global atmospheric cycle of this element, and their contribution to the regional and global atmospheric budgets needs to be reassessed (Gustin et al. 2000; Engle and Gustin 2002).

The St. Petersburg transect (Figs. 1, 3c) was one of the earliest with the LUMEX instrumentation and took place in 1995, crossing the whole St Petersburg city from south to north along $40 \mathrm{~km}$. St. Petersburg is the second largest city in Russia, having a population (2010) of 4,879,566 inhabitants. The area is a major financial and industrial center, and main activities relate to oil and gas trade, shipbuilding, aerospace industry, radio and electronics, software and computers, machine building, heavy machinery and transport, military equipment, mining, instrument manufacture, ferrous and nonferrous metallurgy, chemicals, pharmaceuticals, medical equipment, publishing and printing, food and catering, wholesale and retail, textile and apparel industries. Thus, in many ways, St. Petersburg can be regarded as a potential hot spot for GEM 
contamination. However, most of the data population falls within the 1-30 $\mathrm{ng} \mathrm{m}^{-3}$, whereas a few scattered data reach concentrations above $100 \mathrm{ng} \mathrm{m}^{-3}$. In this respect, Mashyanov and Reshetov (1995) and Pogarev et al. (1997) indicate that there are a number of different sources of outdoor and indoor mercury pollution in St. Petersburg, with local haloes in ambient air of up to $150-300 \mathrm{ng} \mathrm{m}^{-3}$; these concentrations have been recorded around city industrial plants involved in the production of electrical and control instruments, batteries, medicines and over some dump sites.

City of Tuzla is not so large city as previously discussed; however, it is third biggest city and one of most polluted in Bosnia and Herzegovina with population of 120,000 (in 2011). The main source of mercury pollution in the area is soil heavily contaminated by mercury released from the former chloralkali plant using mercury cell technology. During the operation, the chlor-alkali plant emitted large quantity of mercury to air, water and soils. It was shown that mercury evaporation from contaminated soil is the main source of elevated mercury in air reaching concentrations over $100 \mathrm{ng} \mathrm{m}^{-3}$ and even few $\mu \mathrm{g} \mathrm{m}^{-3}$ in vicinity of former chlor-alkali plant (in September 2005). Important potential source of $\mathrm{Hg}$ in air is also a 715 MW coal-burning power plant located in the vicinity of former chlor-alkali industry. It should be noted that elevated concentrations were found not only locally around industrial sources, but also on larger town area with no bigger sources.

The last of our cities discussed here in detail is Guiyang (China; Figs. 1,3d). The city is the capital of the Province of Guizhou (Southwest China) and has a population (2010) of 4,324,561 inhabitants. By the 1970 s, Guiyang became a major producer of aluminum and also produces aerospace engine parts and equipment, industrial and mining equipment, as well as railway vehicles and equipment. Additionally, Guiyang has a large chemical, pharmaceutical, glass, paper and textile industry. However, as noted by Feng et al. (2004), total airborne mercury (gaseous, reactive and particulate $\mathrm{Hg}$; instrument: Tekran 2537A) has a mean concentration of a mere $8.4 \mathrm{ng} \mathrm{m}^{-3}$. Our results for 2010 confirm those of Feng et al. (2004), with most of our data population being between 3 and $30 \mathrm{ng} \mathrm{m}^{-3}$. This is peculiar case for a city that is considered as one of the most seriously polluted in China. Province of Guizhou is also a host of largest $\mathrm{Hg}$ deposits in Wanshan, about $250 \mathrm{~km}$ NE from Guiyang. It is the area of severe $\mathrm{Hg}$ pollution due to $\mathrm{Hg}$ mining and smelting. Large-scale $\mathrm{Hg}$ mining operations stopped in 2004, while some artisanal smelting and mining activities are still present (Dai et al. 2012). Air $\mathrm{Hg}$ concentration range reported for area (Dai et al. 2012) covers the range between 17 and 2,100 $\mathrm{ng} \mathrm{m}^{-3}$; however, in vicinity of abandoned and ongoing artisanal smelting activities, concentrations were much higher, exceeding locally few tens of $\mu \mathrm{g} \mathrm{m}^{-3}$ (May 2011).

Although our data for cities are in a higher range than those for the global medians for the period 1995-2010 (about 0.8-1.8 $\mathrm{ng} \mathrm{m}^{-3}$; Slemr et al. 2011), they are nevertheless far from being a risk for human populations. We shall address again this crucial matter in the following section "Temporal evolution of measurements."

\section{Areas with natural emissions from volcanoes}

Volcanic GEM emission estimates suggest a figure of 112-700 tones per year (Nriagu and Becker 2003; Pyle and Mather 2003). Quiescent volcanic degassing would account for $10 \%$ of the yearly estimated flux of GEM, and small eruptions may contribute about $75 \%$ of the total, whereas those of catastrophic character would overwhelm the atmospheric budget of the element (Pyle and Mather 2003; Oyarzun et al. 2005; Fig. 5). In this respect, during the first 2 weeks of September 1980 (during a noneruptive phase), the daily $\mathrm{Hg}$ output from the Mt St Helens system ranged from 200 to 1,700 $\mathrm{kg}$ (Varekamp and Buseck 1981).

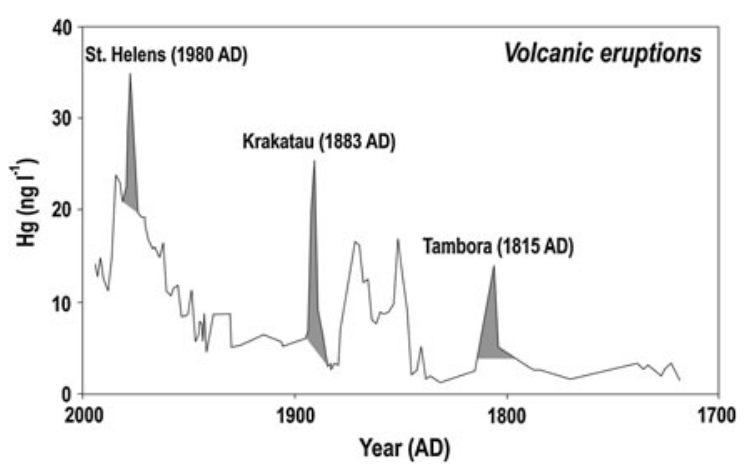

Fig. 5 Mercury contents recorded in the Fremont Glacier ice core; Shaded areas represent the $\mathrm{Hg}$ volcanic input of the Tambora, Krakatau and St. Helens catastrophic eruptions (based on Schuster et al. 2002) 
Thus, the natural sources can be more important than the credit (or discredit) they usually receive for their contribution to $\mathrm{Hg}$ emission budget. We should anyway keep in mind that it was volcanic activity what actually gave rise to the world's largest natural $\mathrm{Hg}$ accumulation: the Almadén district ore deposits (Higueras et al. 2000). Perhaps mercury isotope compositions will contribute much in the future to elucidate the actual sources of this pollutant and their relative importance (e.g., Feng et al. 2010).

Mt. Etna (Sicily) is one of the most active volcanoes in the world and one of the largest contributors of magmatic volatiles to the environment. Mercury concentrations have been measured on Mt. Etna during several campaigns, carried out between 2004 and 2009 in fumaroles, bubbling and soil gases as well as in the air inside and across the volcanic plume. In addition, $\mathrm{Hg}$ fluxes have been measured by flux chamber technique (Kotnik et al. 2005). Mercury concentrations measured in air on moving at the ground surface below the volcanic plume in November 2004 ranged between 4 and $30 \mathrm{ng} \mathrm{m}^{-3}$ in the eastern and southeaster flanks of the volcano up to an altitude of $1,500 \mathrm{~m}$ a.s.l., and between 65 and $132 \mathrm{ng} \mathrm{m}^{-3}$ in vicinity of the summit craters at altitudes from 2,000 to 3,000 $\mathrm{m}$ a.s.l. A profile of $\mathrm{Hg}$ in the air below the volcanic plume carried out on helicopter on November 2006 showed Hg concentrations up to $60 \mathrm{ng} \mathrm{m}^{-3}$. $\mathrm{Hg}$ contents in fumarole and soil gases in the lower SW and E flanks showed temporal variations, depending on volcanic activity, which reached the highest values in fall 2005 (up to $240 \mathrm{ng} \mathrm{m}^{-3}$ ). $\mathrm{Hg}$ levels in the crater plume and fumarole gases near the summit of the volcano ranged between 2 and $60 \mu \mathrm{g} \mathrm{m}^{-3}$ (June 2007), with the highest values at site Torre del Filósofo (2,900 m a.s.l. on the S flank) and on the rim of the Summit Crater. Highest $\mathrm{Hg}$ fluxes were measured in gases of mud volcanoes Vallone Salato and Salinelle del Strato reaching values up to $1,300 \mathrm{ng} \mathrm{m}^{-2} \mathrm{~h}^{-1}$. In Table 1 , only measurements of air concentrations around volcano below altitudes of $1,500 \mathrm{~m}$ a.s.l. are presented.

Similar to Sicily, Puyehue and Cordón Caulle are two most active volcanoes in the Andes of Ranco Province, South Chile. The Puyehue-Cordón Caulle area is one of the main sites of exploration for geothermal power in Chile. Geothermal activity is manifested on the surface of Puyehue and Cordón
Caulle as several boiling springs, solfataras and fumaroles. Renewed activity of the Puyehue volcano resulted in the eruption started in June 2011, when the ash cloud reached a height of 12,000 meters. Detailed car mapping of area was performed in February 2007 covering the area between San Carlos de Barilloche, Argentina, and south and east flanks of Puyehue volcano, Chile. During the survey, the highest $\mathrm{Hg}$ concentrations were recorded even $50 \mathrm{~km}$ downwind from volcanic area reaching values up to $10 \mathrm{ng} \mathrm{m}^{-3}$. More southern in Nahuel Huapi National Park and San Carlos de Barilloche, only background values $\left(\sim 2 \mathrm{ng} \mathrm{m}^{-3}\right)$ were observed.

\section{Pristine areas}

Our Group 4 data sets correspond to (at least in principle) pristine locations. The first one corresponds to the Kruger national Park in South Africa (Figs. 1, 3e). The park was established in 1898 to protect the wildlife of the South African Lowveld, constitutes the largest animal reserve in South Africa and covers about $19,000 \mathrm{~km}^{2}$. As expected for a wild realm lacking cities and/or industries, the surveys showed very low values in the range of 0.3 to $10 \mathrm{ng} \mathrm{m}^{-3}$; the surveys were carried out in 2011 and comprised the camps of Punda Maria and Tamboti. On the other hand, the $32 \mathrm{~km}$ transect of Kajaani-Vuokatti (Finland; Figs. 1, 3f) covers the typical Finnish landscape of woods and lakes, and was done in 2012. Kajaani is the capital of the Kainuu region and has 38,038 inhabitants (2012). The only industrial activity in the area is that of the Talvivaara mine, one the largest Finnish nickel mines, a site located about $28 \mathrm{~km}$ from Kajaani. The data set resembles that of the Kruger Park in that both have most of the population within the range $0.3-10 \mathrm{ng} \mathrm{m}^{-3}$, thus suggesting mostly pristine environmental conditions despite open-pit mining activity at Talvivaara.

Measurements in southern Brazil, between Porto Alegre on North and Rio Grande, were done mostly on road transect between mentioned cities on west (April 2012) or east (October 2012) side of Patos Lagoon, coastal area of Rio Grande, and most southern part of Patos Lagoon. Coast is formed by two great estuarine lagoons, the Lagoa dos Patos and Lagoa Mirim, which are separated from the ocean by two sandy, partially barren peninsulas. All measurements were made in transects with resolution of $1 \mathrm{~s}$. Eastern part is a wide 
coastal zone only slightly elevated above the sea level between Patos Lagoon on W and Atlantic ocean on E, while way along western part of lagoon is more inland, but still very flat, only few $\mathrm{m}$ a.s.l. Area between Porto Alegre and Rio Grande is mostly pristine used for cattle breeding and agriculture; however, there are some bigger towns with populations up to 450,000 (i.e., Pelotas, Sao Lorenco, Camaqua) and industry that represents several possible $\mathrm{Hg}$ sources to the atmosphere as well as to the lagoons (i.e., thermal power plants, cement plants, fertilizers production and ports) located mostly in biggest cities (Pelotas, Rio Grande and Porto Alegre). Measured Hg concentrations were typically around background values $\left(\sim 2 \mathrm{ng} \mathrm{m}^{-3}\right)$ in pristine areas between cities, while concentrations in cities were slightly higher (4-6 $\mathrm{ng} \mathrm{m}^{-3}$ ). In a very limited area around a new fish factory in Rio Grande, $\mathrm{Hg}$ in air reached values up to $16 \mathrm{ng} \mathrm{m}^{-3}$. Lower concentrations in air were found over Patos Lagoon (1.51 $\mathrm{ng} \mathrm{m}^{-3}$ in average) than over the land around lagoon $\left(2.07 \mathrm{ng} \mathrm{m}^{-3}\right)$.

Further information regarding the data distribution sets discussed above and other sites belonging to Groups 1-4 can be obtained from Table 1 .

Temporal evolution of measurements

An important issue regarding mercury atmospheric measurements concerns its temporal evolution. Authors such as Cole et al. (2013), Ebinghaus et al. (2011), Kim et al. (2005), Kock et al. (2005) and Slemr et al. (2003, 2011) among others have detected a descent in atmospheric mercury levels with time, due to the regulations banning its usage and manipulation (Mercury Policy Project 2008; DEFRA 2010). Our data are not the most appropriate to analyze this question, since they come from different locations, with important differences in typology of the possible sources, producing different discrete effects on the surrounding environment. So, Fig. 6a shows the general tendency for our data, considering two differentiated subpopulations: European and South American data; on the other hand, in Fig. 6b, we have eliminated the data from sites that could be considered as anomalous or clearly contaminated, such as Almadén (Spain), Monte Amiata (Italy) and Tuzla (Bosnia \& Herzegovina) for Europe, and Apolobamba (Bolivia) and El Callao (Venezuela) for South America. Considering the rest of data, clear descending
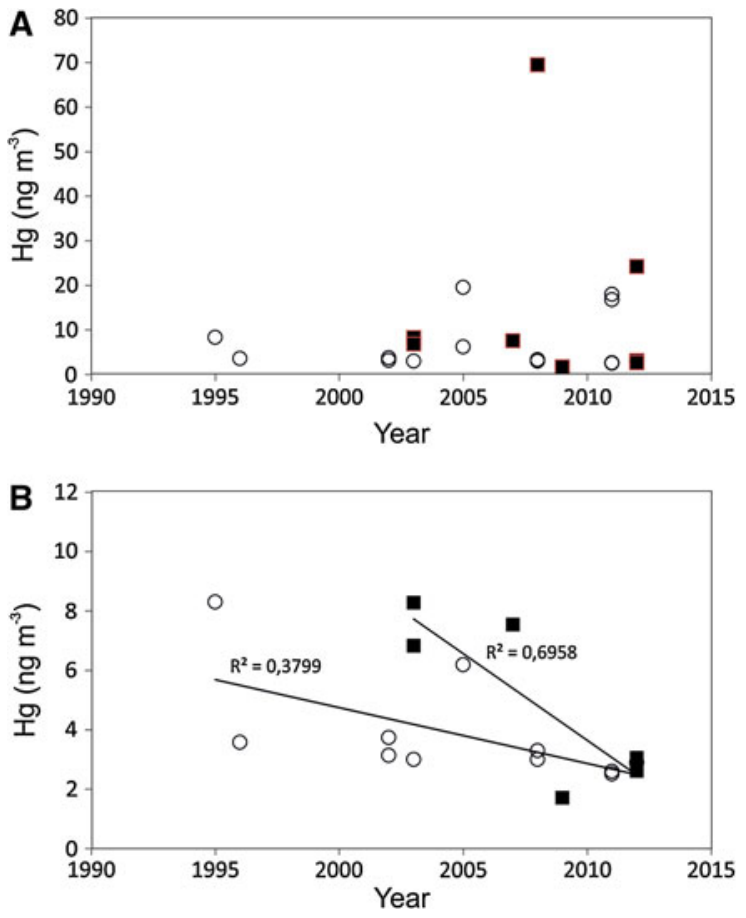

Fig. 6 Plot of measured $\mathrm{Hg}$ concentrations versus year of measurements; $\mathbf{a}$ : all data; $\mathbf{b}$ : excluding data from most polluted sites (see text). Circles: Data from Europe; Filled squares Data from South America

tendency arises for both data sets, probably as an indication of the general worldwide tendency of mercury reduction caused by the mentioned governmental measures. This descent has also been demonstrated in discrete highly polluted sites after the performance of source reclamation works (Higueras et al. 2013).

Atmospheric mercury concentrations: when should we worry?

The US EPA (2012) indicates that a toxic substance is the one that can be harmful to the environment and to human health if inhaled, swallowed or absorbed through the skin. In addition to this definition, the HESIS (2008) adds the amount (dose) of the substance that is required to cause harm. The HESIS (2008) also indicates that the toxicity of a substance depends on its chemical structure, the extent to which the substance is absorbed by the body and the body ability to detoxify the substance by elimination. Thus, the point is when and why should we get worried regarding a toxic substance. This is the key issue here because we may 
end up mixing the concepts of hazard and risk. While hazard is something with the potential to cause harm, risk is the likelihood that the harm will occur from exposure to the hazard. In this regard, a contaminant such as GEM is (no doubt) a hazard, although the big question is whether this contaminant may pose (or not) a risk to human health.

We all know the story of the shepherd boy who repeatedly tricked nearby villagers by making them to believe that a wolf was attacking his flock of sheep. One day, when the wolf actually appeared in the scene, the villagers did not believe the cries for help and the flock was slaughtered. End of the story? Not long ago, Ladle et al. (2004a, b) from Oxford University called the attention of the scientific community on the dangers of crying wolf. Although their letter to the journal Nature was on another controversial topic (climate change and mass extinction of biological species), the basic issue raised by these authors remains the same for a series of environmental issues. Ladle et al. (2004a, b) stated that "media coverage of conservation research is usually welcomed by the scientists involved, but there are pitfalls to heed. Damaging simplifications of research findings may expose conservationists to accusations of crying wolf and play directly into the hands of anti-environmentalists." In this regard, if we load the Google search engine with the words "mercury danger," about $49,300,000$ results turn up into the screen. This is a very relevant issue, because if anyone raises the alarm just because the instruments detect the existence of GEM, we shall be doing a poor service to science and society in more than a way. In this respect, Oyarzun et al. (2007) reviewed key health and safety regulation regarding atmospheric mercury, which provides valuable information to understand when a hazard becomes a risk. The World Heath Organization (WHO 2000) indicates that concentrations of $\mathrm{Hg}$ in air in the range of $15,000-30,000 \mathrm{ng} \mathrm{m}^{-3}$ may have effects on human physiology (tremors, renal tubular effects, change in plasma enzymes and others). However, the same organization recognizes that these figures are rough estimates and that it seems appropriate to use an uncertainty factor of 20 ; thus, an estimated guideline for mercury concentration in air would be $1,000 \mathrm{ng} \mathrm{m}^{-3}$ (WHO 2000). The US EPA (2007a, b; Region 5) recommends the following: if GEM concentrations are between 1,000 and $10,000 \mathrm{ng} \mathrm{m}^{-3}$, relocation of residents should be scheduled as soon as possible. For concentrations above $10 \mu \mathrm{g} \mathrm{m}^{-3}\left(>10,000 \mathrm{ng} \mathrm{m}^{-3}\right)$, residents should be relocated immediately. In this respect, GEM concentrations above the range $10^{3}-10^{4} \mathrm{ng} \mathrm{m}^{-3}$ are usually found in mercury mining sites or mercury metallurgical installations (e.g., Higueras et al. 2005, 2006; Kotnik et al. 2005). On the other hand, the current US Occupational Safety and Health Administration permissible exposure limit for GEM is $0.1 \mathrm{mg} \mathrm{m}^{-3}\left(100,000 \mathrm{ng} \mathrm{m}^{-3}\right)$ of air as a ceiling limit (US OSHA, 2007). Besides, the National (US) Institute for Occupational Safety and Health (NIOSH) has established a recommended exposure limit for GEM of $0.05 \mathrm{mg} \mathrm{m}^{-3}\left(50,000 \mathrm{ng} \mathrm{m}^{-3}\right)$ as a time-weighted average (TWA) for up to a 10-h workday and a 40-h workweek (US OSHA, 2007). The American Conference of Governmental Industrial Hygienists has assigned to GEM a threshold limit value of $0.025 \mathrm{mg} \mathrm{m}^{-3}\left(25,000 \mathrm{ng} \mathrm{m}^{-3}\right)$ as a TWA for a normal 8-h workday and a 40-h workweek (US OSHA, 2007). The minimum risk level (MRL) for chronic inhalation of GEM is $0.0002 \mathrm{mg} \mathrm{m}^{-3}\left(200 \mathrm{ng} \mathrm{m}^{-3}\right)$ (US OSHA, 2007; ATSDR, 2012). An MRL is an estimate of the daily human exposure to a hazardous substance that is likely to be without appreciable risk of adverse (noncancer) health effects over a specified duration of exposure. The US EPA reference concentration for inhalation is calculated to be $0.0003 \mathrm{mg} \mathrm{m}^{-3}$ (300 $\mathrm{ng} \mathrm{m}^{-3}$ ) (TWA) (US OSHA, 2007).

If we take the strictest regulation regarding GEM (US OSHA, 2007; ATSDR, 2012), we reach the conclusion that very few data in our surveys (Figs. 2, 3 ) are above the figure of $200 \mathrm{ng} \mathrm{m}^{-3}$. To find "above US OSHA" populations, one has to get very near to active sources of mercury such as those one may expect in artisanal gold mining sites, where the careless use of mercury may result in higher than normal emissions of GEM. In this regard, what we should call "normal" and "anomalous"? Our "pristine sites" (Group 3) have concentrations within a range of $0.3-10 \mathrm{ng} \mathrm{m}^{-3}$ (Fig. 3e, f). The range expands a bit in cities (Group 2) and may reach an upper boundary of $30 \mathrm{ng} \mathrm{m}^{-3}$ or even reach $250 \mathrm{ng} \mathrm{m}^{-3}$ (Fig. 3c), although the latter is an extremely rare concentration. Thus, the big issue here is whether a hazard such as GEM can become a risk. Not long ago, part of this team conducted four surveys in two plant herbaria in Madrid (Spain), finding GEM 
concentrations in the order of thousands to tens of thousands of $\mathrm{ng} \mathrm{m}^{-3}$ (Oyarzun et al. 2007). The reason why is simple: a classic threat to preservation of herbarium specimens are insects and fungi, for which a series of chemical deterrents were used in the past, among them mercuric chloride $\left(\mathrm{HgCl}_{2}\right)$. Mercuric chloride was widely used until the 1970s and even the early 1980s in some herbaria (Clark 1986), when health risks made it unsuitable for specimen preservation (Oyarzun et al. 2007). The GEM concentrations found at the Royal Botanical Garden (CSIC) and Biology II Department (UCM) herbaria (Madrid) were by any standard extremely high, and taken into account that people worked under these conditions, we can properly call these concentrations a "risk."

An entirely different matter is Group 2 (the cities), where we could not find the slightest evidence for a case of GEM generalized pollution. This despite the existence of oil refineries, heavy traffic, and even the existence of coal-fired plants. This calls for a reassessment regarding the importance of coal combustion plants (Carpi 1997) and oil refineries (O'Rourke and Connolly 2003) as Hg sources; either their importance is not that high or the clean air has a dilution power much more important than we ever thought. Whatever the case is, we should also keep in mind that almost as important as the anthropogenic sources are those related to the volcanic activity, either during quiescent volcanic degassing or catastrophic eruptions (e.g., Nriagu and Becker 2003; Pyle and Mather 2003; Oyarzun et al. 2005; Fig. 4).

A final consideration regards Group 1, where the mining of alluvial gold using mercury for amalgamation is or has been performed. It is in this group where we found the most important concentrations of GEM. Artisanal and small-scale gold mining (ASGM) in tropical settings has called the attention of many environmental groups for most of the last decades, which is partly because of the assumption that a "drop" of mercury can contaminate giant volumes of river water. However, as we already discussed above, mercury is only slightly soluble in water (e.g., WHO 2005; Health Canada 2009); in other words, the reaction $\mathrm{Hg}^{0}=\mathrm{Hg}^{2+}+2 \mathrm{e}^{-}\left(\mathrm{E}^{0}=+0.85\right)$ will be of lesser importance, particularly in organic-matterrich, oxygen-poor waters as we may expect in some of jungle river waters such as those of Amazon basin, where oxidation of the abundant organic matter consumes $\mathrm{O}_{2}$ (e.g., Richey et al. 1988; Amon and Benner 1996). On the other hand, the emitted GEM is oxidized to $\mathrm{Hg}_{\text {gas }}^{2+}$ in the atmosphere, a reaction mediated by ozone $\left(\mathrm{O}_{3}\right)$ (e.g., Lindberg and Stratton 1998; Sillman et al. 2005) and halogen species (e.g., $\mathrm{Cl}, \mathrm{Br}, \mathrm{ClO}, \mathrm{BrO}$ ) (e.g., Berg et al. 2008; Sigler et al. 2009). However, the residence time of $\mathrm{Hg}_{\text {gas }}^{2+}$ in the atmosphere is very short (in the range of days) and its concentration is very low, being typically in a very low proportion of the total gaseous mercury (Sprovieri et al. 2010). As measured at the Almadén district and Puertollano (Fig. 1), the mean concentration of $\mathrm{Hg}_{\text {gas }}^{2+}$ is typically less $0.1 \%$ (unpublished data by this team), which can be explained by the absence of sea-salt aerosols (e.g., Berg et al. 2008) in inland Spain.

Besides, and although this matter goes beyond the scope of this paper, let us state nevertheless that the oxidation rate of metallic $\mathrm{Hg}^{0}$ to $\mathrm{Hg}_{\text {aq. }}^{2+}$ (aq. : aqueous) in the organic-matter-rich fluvial waters of the tropical forests (where most of the present ASGM takes place) is a key matter to be evaluated in relation to the actual risks posed by a hazard such as atmospheric mercury. This is because the most dangerous species of mercury for human health is methylmercury, and for that to form, bacterial activity and $\mathrm{Hg}_{\text {aq. }}^{2+}$ is required (e.g., Hamdy and Noyes 1975; Lambertsson and Matsnilsson 2006). In fact, bacterial production of methylmercury can be regarded as a detoxification metabolic process against mercurial compounds, which results in conversion of inorganic mercury $\left(\mathrm{Hg}_{\mathrm{aq}}^{2+}\right)$ to the organic form $\left(\mathrm{CH}_{3} \mathrm{Hg}_{\text {aq. }}^{+}\right)$ultimately leading to the excretion of this species to the environment (e.g., Hamdy and Noyes 1975). Lambertsson and Matsnilsson (2006) indicate that although the $\mathrm{Hg}_{\text {aq. }}^{2+}$ availability is a fundamental prerequisite for $\mathrm{Hg}$ methylation, the correlation between $\mathrm{Hg}_{\text {aq. }}^{2+}$ and $\mathrm{CH}_{3} \mathrm{Hg}_{\text {aq. }}^{+}$is weak, and factors affecting bacterial activity are important. They go further concluding that the amount of organic matter is also a major factor affecting methylmercury formation, whereas the total amount of $\mathrm{Hg}$ has, surprisingly, little or no influence. In this regard, as indicated by Sunderland et al. (2009), atmospheric deposition is widely recognized as the dominant $\mathrm{Hg}$ source to open ocean regions, and in this respect, these authors have observed that there is a positive linear relationship between increasing rates of organic 
carbon remineralization and methylated mercury concentrations, which suggests a link between organic carbon and mercury methylation in the open oceans. Given that fish can eventually incorporate this methylated mercury, this is a hazard that society has to deal with. However, to our knowledge, higher frequency of neurological signs characteristic of methylmercury poisoning has only be detected in the area of influence of the Minamata Bay in Japan, that is, in the Shiranui Sea coastal villages (Ninomiya et al. 1995). This suggests that truly elevated concentrations of methylmercury (such as those that can be provided by uncontrolled industries that use mercury) must be present in the waters to induce a real risk regarding this dangerous pollutant. Furthermore, the authors of a comprehensive and long-lasting (27 years) study undertaken by a team of the University of Rochester (New York; Myers et al. 2000) indicate that: "the clinical studies that our team has carried out in Samoa, Peru and the Seychelles provide no evidence that consuming large quantities of fish is associated with adverse effects on adults or children." They went further stating that: "restricting fish consumption without clear justification could potentially adversely affect children's development. This is especially true in societies where fish is the primary source of protein."

But let us return to our study case on mercury gas (s.s.) and gold alluvial mining; another hazard is generated by (1) the accidental but usually common losses of $\mathrm{Hg}_{\text {metal }}^{0}$; and (2) the heating of $\mathrm{Hg}-\mathrm{Au}$ amalgams to purify gold; given that mercury is very volatile, these processes result in either partial (1) or total (2) gasification of mercury ( $\left.\mathrm{Hg}_{\text {metal }}^{0} \rightarrow \mathrm{GEM}\right)$. While both are of much concern, the second one directly affects to the miners performing the burning. Once mercury is in the lungs, the element is oxidized, thus forming $\mathrm{Hg}^{2+}$ complexes that are soluble in the body fluids, which can induce permanent damage to the nervous system (Veiga et al. 2005). In this regard, whoever has inspected an ASGM operation has been able to observe firsthand the precarious conditions in which the $\mathrm{Hg}-\mathrm{Au}$ amalgam is dealt with. Shanty towns characterize this landscape of misery inhabited by people that did not choose but somehow were forced to work under appalling conditions (Spiegel and Veiga 2005). It is within this landscape where the most serious risks for human health are present. In this respect, the El Callao site in Venezuela (Veiga et al.
2005) may be one of the few cases in our Groups 1-3 in which we can properly cry wolf, as we are not addressing the "potentiality" of a hazard to be become a risk, but of a case in which the people (miners and their families) are indeed facing a risk.

\section{Conclusions}

As seen in the discussion and Figs. 2, 3, and Table 1, most of the data sets for Group 2 (cities) are within low GEM concentrations that rarely exceed $30 \mathrm{ng} \mathrm{m}^{-3}$, which is not too far away from our "control" Group 3 data sets (mostly pristine environmental settings). In this respect, $30 \mathrm{ng} \mathrm{m}^{-3}$ is 6.6 times less than the most restrictive US OSHA (2007) \& ATSDR (2012) threshold at $200 \mathrm{ng} \mathrm{m}^{-3}$. The low GEM levels obtained for cities become a true oddity in the case of Puertollano $\left(\mathrm{GEM}<10 \mathrm{ng} \mathrm{m}^{-3}\right.$ ), a small but highly industrialized city which (1) is relatively close to the Almadén (world's largest) mercury mining district (Fig. 1); (2) hosts one of the largest oil refineries in Spain; and last but not least (3) hosts two coal-fired power plants. Let us remember that all of these are regarded as important GEM sources. Given that the instrumental measurements have been checked many times along the years and validated, we must come to the conclusion that either the potential sources of GEM are not as important as thought, or the air is constantly recycled thus keeping low levels of atmospheric mercury. In our opinion, these are not necessarily mutually exclusive views. Besides, as shown by previous works (Higueras et al. 2004, 2005; Llanos et al. 2010; Martínez-Coronado et al. 2011), clean air indeed dilutes high concentrations of GEM in the field in very short distances (a few hundreds of meters or less), which holds true even for highly polluted ( $>40,000 \mathrm{ng} \mathrm{m}^{-3}$ ) indoor settings as shown by our works at the Royal Botanical Garden herbarium of Madrid (Oyarzun et al. 2007). Based on all this, we must conclude that GEM high concentrations are to be regarded for what they are, that is, localized phenomena that easily fade away in short distances. However, the fact that high concentrations of GEM are "localized" does not mean that they do not pose a major risk for those working in close proximity to the source, such as the case of the precarious installations used by the gold artisanal miners, or some other working 
installations, and even in some domestic situations. We believe that this final statement would even pass the rather dubious and strict legal test imposed by the US Supreme Court regarding the concept of "clear and present danger" (e.g., Boudin 1952), because in this case, we are not addressing just a potential danger but one that is likely to cause harm if it is not immediately neutralized.

Acknowledgments This work was supported by Grants CGL2009-13171 and CTM2012-33918 from the Spanish Ministry of Economy and Competitiveness and PII1I09-01424389 from the Castilla-La Mancha (Spain) Regional Government. $\mathrm{PH}$ and RO warmly thank all the researchers that kindly decided to contribute with their data on GEM to this paper. Our gratitude goes to all of them.

\section{References}

Acosta, J. A., Martínez-Martínez, S., Faz, A., Millán, R., Muñoz, M. A., Terán, T., et al. (2011). Characterization of the potential mercury contamination in the Apolobamba gold mining area, Bolivia. Spanish Journal of Soil Science, 1, $86-99$.

Aiuppa, A., Bagnato, E., Witt, M. L. I., Mather, T. A., Parello, F., Pyle, D. M., et al. (2007). Real-time simultaneous detection of volcanic $\mathrm{Hg}$ and $\mathrm{SO}_{2}$ at La Fossa Crater, Vulcano (Aeolian Islands, Sicily). Geophysical Research Letters, 34, L21307.

Al-Batanony, M. A., Abdel-Rasul, G. M., Abu-Salem, M. A., Al-Dalatony, M. M., \& Allam, H. K. (2013). Occupational exposure to mercury among workers in a fluorescent lamp factory, Quisna industrial zone, Egypt. International Journal of Occupational \& Environmental Medicine, 4, 149-156.

Almeida, M. D., Marins, R. V., Paraquettia, H. H. M., \& Lacerda, L. D. (2008). Methodology optimization and application for measurement of gaseous elemental mercury in the Amazon atmosphere. Journal of the Brazilian Chemical Society, 19, 1290-1297.

Amon, R. M. W., \& Benner, R. (1996). Photochemical and microbial consumption of dissolved organic carbon and dissolved oxygen in the Amazon River system. Geochimica et Cosmochimica Acta, 60, 1783-1792.

ATSDR/EPA National Mercury. Cleanup Policy Workgroup. Action Levels For Elemental Mercury Spills. March 22, 2012. http://www.atsdr.cdc.gov/emergency_response/Action_ Levels_for_Elemental_Mercury_Spills_2012.pdf. Accessed 28 June 2013.

Aymaz, S., Gross, O., Krakamp, B., Ortmann, M., Dienes, H. P., \& Weber, M. (2001). Membranous nephropathy from exposure to mercury in the fluorescent-tube-recycling industry. Nephrology, Dialysis, Transplantation, 16, 2253-2255.

Berg, T., Sekkesæter, S., Steinnes, E., Valdal, A. K., \& Wibetoe, G. (2008). Springtime depletion of mercury in the European
Arctic as observed at Svalbard. Science of the Total Environment, 304, 43-51.

Bernhoft, R. A. (2012). Mercury toxicity and treatment: A review of the literature. International Journal of Environmental and Public Health. Article no. 460508.

Bose-O'Reilly, S., Drasch, G., Beinhoff, C., Rodrigues-Filho, S., Roider, G., Lettmeier, B., et al. (2010a). Health assessment of artisanal gold miners in Indonesia. Science of the Total Environment, 408, 713-725.

Bose-O'Reilly, S., Drasch, G., Beinhoff, C., Tesha, A., Drasch, K., Roider, G., et al. (2010b). Health assessment of artisanal gold miners in Tanzania. Science of the Total Environment, 408, 796-805.

Boudin, L. B. (1952). Seditious doctrines and the clear and present danger rule. Virginia Law Review, 38, 143-186.

Brown, R. J. C., Pirrone, N., van Hoek, C., Horvat, M., Kotnik, J., Wangberg, I., et al. (2010a). Standardisation of a European measurement method for the determination of mercury in deposition: Results of the field trial campaign and determination of a measurement uncertainty and working range. Accreditation and Quality Assurance, 15, 359-366.

Brown, R. J. C., Pirrone, N., Van Hoek, C., Sprovieri, F., Fernandez, R., \& Toté, K. (2010b). Standardisation of a European measurement method for the determination of total gaseous mercury: Results of the field trial campaign and determination of a measurement uncertainty and working range. Journal of Environmental Monitoring, 12(3), 689-695.

Carpi, A. (1997). Mercury from combustion sources: A review of the chemical species emitted and their transport in the atmosphere. Water, Air, and Soil pollution, 98, 241-254.

Chan, H. M., \& Egeland, G. M. (2004). Fish consumption, mercury exposure, and heart diseases. Nutrition Reviews, $62,68-72$.

Clark, S. (1986). Preservation of herbarium specimens: an archive conservators approach. Taxon, 35, 675-681.

Clarkson, T. W., \& Magos, L. (2006). The toxicology of mercury and its chemical compounds. Critical Reviews in Toxicology, 36, 609-662.

Cole, A. S., Steffen, A., Pfaffhuber, K. A., Berg, T., Pilote, M., Poissant, L., et al. (2013). Ten-year trends of atmospheric mercury in the high Arctic compared to Canadian subArctic and mid-latitude sites. Atmospheric Chemistry and Physics, 13, 1535-1545.

Dai, Z. H., Feng, X: B., Sommar, J., \& Fu, X. W. (2012). Spatial distribution of mercury deposition fluxex in Wanshan $\mathrm{Hg}$ mining area, Guizhu province, China. Atmospheric Chemistry and Physics, 12, 6207-6218.

DEFRA (2010). The mercury export and data (enforcement) regulations 2010: guidance notes, Department for Environment, Food and Rural Affairs (United Kingdom), http://archive.defra.gov.uk/environment/quality/chemicals/ documents/mercury-export-data-regs.pdf. Accessed 25 Feb 2013.

Ebinghaus, R., Jennings, S. G., Kock, H. H., Derwent, R. G., Manning, A. J., \& Spain, T. G. (2011). Decreasing trends in total gaseous mercury observations in baseline air at Mace Head, Ireland from 1996 to 2009. Atmospheric Environment, 45, 3475-3480. 
Echeverria, D., Heyer, N. J., Martin, M. D., Naleway, C. A., Woods, J. S., \& Bittner, A. C., Jr. (1995). Behavioral effects of low-level exposure to $\mathrm{Hg}^{\circ}$ among dentists. Neurotoxicology and Teratology, 17, 161-168.

EN 15852. (2010). Ambient air quality-Standard method for the determination of total gaseous mercury. http://www.enstandard.eu/csn-en-15852-ambient-air-quality-standardmethod-for-the-determination-of-total-gaseous-mercury/. Accessed 28 June 2013.

Engle, M. A., \& Gustin, M. S. (2002). Scaling of atmospheric mercury emissions from three naturally enriched areas: Flowery Peak, Nevada; Peavine Peak, Nevada; and Long Valley Caldera, California. Science of the Total Environment, 290, 91-104.

European Standards. (2013). CSN EN 15852-Ambient air quality - Standard method for the determination of total gaseous mercury. http://www.en-standard.eu/en-15852-ambientair-quality-standard-method-for-the-determination-of-totalgaseous-mercury. Accessed 25 Feb 2013.

Feng, X., Foucher, D., Hintelmann, H., Yan, H., He, T., \& Qiu, G. (2010). Tracing mercury contamination sources in sediments using mercury isotope compositions. Environmental Science and Technology, 44, 3363-3368.

Feng, X., Shang, L.,Wang, S., Tang, S., Zheng, W. (2004). Temporal variation of total gaseous mercury in the air of Guiyang, China. Journal of Geophysical Research D: Atmospheres, 109(D03303), 1-9.

Fernández-Patier, R., \& Ramos-Díaz, M. C. (2012). Informe del Ejercicio de lntercomparación de Mercurio Gaseoso total en aire ambiente "IN SITU" (año 2011). Ined. Repport, Instituto de Salud Carlos III, Centro Nacional de Sanidad Ambiental, Área de Contaminación Atmosférica. Ministerio de Economía y Competitividad, España, 7 pp. In Spanish.

Fu, X., Feng, X., Sommar, J., \& Wang, S. (2012). A review of studies on atmospheric mercury in China. Science of the Total Environment, 421-422, 73-81.

Fu, X. W., Feng, X. B., \& Zhang, H. (2011). Atmospheric total gaseous mercury concentration in Guiyang: measurements intercomparison with Lumex RA-915AM and Tekran 2537A. Chinese Journal of Ecology, 30, 939-943.

Garcia-Sanchez, A., Contreras, F., Adams, M., \& Santos, F. (2006). Airborne total gaseous mercury and exposure in a Venezuelan mining area. International Journal of Environmental Health Research, 16, 361-373.

García-Sánchez, A., Contreras, F., Adams, M., \& Santos, F. (2006). Atmospheric mercury emissions from polluted gold mining areas (Venezuela). Environmental Geochemistry and Health, 28, 529-540.

Gosar, M., Pirc, S., Sajn, R., Bidovec, M., Mashyanov, N. R., \& Sholupov, S. E. (1997). Distribution of mercury in atmosphere over Idrija, Slovenia. Environmental Geochemistry and Health, 19, 101-110.

Grandjean, P., Satoh, H., Murata, K., \& Eto, K. (2010). Adverse effects of methylmercury: Environmental health research implications. Environmental Health Perspectives, 118, 1137-1145.

Gray, J. E., Hines, M. E., Higueras, P. L., Adatto, I., \& Lasorsa, B. K. (2004). Mercury speciation and microbial transformations in mine wastes, stream sediments, and surface waters at the Almadén Mining District, Spain. Environment Science and Technology, 38, 4285-4292.

Gul Oz, S., Tozlu, M., Yalcin, S. S., Sozen, T., \& Sain Guven, G. (2012). Mercury vapor inhalation and poisoning of a family. Inhalation Toxicology, 24, 652-658.

Gustin, M. S., Lindberg, S. E., Austin, K., Coolbaugh, M., Vette, A., \& Zhang, H. (2000). Assessing the contribution of natural sources to regional atmospheric mercury budgets. Science of the Total Environment, 259, 61-71.

Hamdy, M. K., \& Noyes, R. (1975). Formation of methyl mercury by bacteria. Applied Microbiology, 30, 424-432.

Harada, M. (1995). Minamata disease: methylmercury poisoning in Japan caused by environmental pollution. CRC Critical Reviews in Toxicology, 25, 1-24.

Health Canada (2009). Mercury. Environmental and Workplace Health, Health Canada Federal Department, http://www. hc-sc.gc.ca/ewh-semt/pubs/water-eau/mercury-mercure/ i-eng.php. Accessed 25 Feb 2013.

HESIS (2008). Understanding toxic substances. Hazard Evaluation System and Information Service, California Department of Public Health, http://www.cdph.ca.gov/programs/ hesis/Documents/introtoxsubstances.pdf.

Higueras, P., Esbrí, J. M., Oyarzun, R., Llanos, W., MartínezCoronado, A., Lillo, J., et al. (2013). Industrial and natural sources of gaseous elemental mercury in the Almadén District (Spain): An updated report on this issue after the cease of mining and metallurgical activities in 2003 and major land reclamation works. Environmental Research, 125, 197-208.

Higueras, P., Llanos, W., García, M. E., Millán, R., \& Serrano, C. (2012). Mercury vapours emissions from the Ingenios in Potosí (Bolivia). Journal of Geochemical Exploration, $116,1-7$.

Higueras, P., Oyarzun, R., Lillo, J., Oyarzún, J., \& Maturana, H. (2005). Atmospheric mercury data for the Coquimbo region, Chile: influence of mineral deposits and metal recovery practices. Atmospheric Environment, 39, 7587-7596.

Higueras, P., Oyarzun, R., Lillo, J., Sánchez Hernández, J. C., Molina, J. A., Esbrí, J. M., et al. (2006). The Almadén district (Spain): Anatomy of one of the world's largest $\mathrm{Hg}$ contaminated sites. Science of the Total Environment, 356, 112-124.

Higueras, P., Oyarzun, R., Munhá, J., \& Morata, D. (2000). Palaeozoic magmatic-related hydrothermal activity in the Almadén syncline (Spain): a long-lasting Silurian to Devonian process? Trans. Instn. Min. Metall. Sect. B: Applied Earth Science, 109, 199-202.

Higueras, P., Oyarzun, R., Oyarzún, J., Maturana, H., Lillo, J., \& Morata, D. (2004). Environmental assessment of copper-gold-mercury mining in the Andacollo and Punitaqui districts, northern Chile. Applied Geochemistry, 19, 1855-1864.

Holmes, C. D., Jacob, D. J., Corbitt, E. S., Mao, J., Yang, X., Talbot, R., et al. (2010). Global atmospheric model for mercury including oxidation by bromine atoms. Atmospheric Chemistry and Physics, 10, 12037-12057.

Kasznia-Kocot, J., Dbkowska, B., Muszyńska-Graca, M., Brewczyński, P. Z., \& Złotkowska, R. (2008). Domestic accidental mercury vapor intoxication in families. Journal of Public Health, 30, 113. 
Kim, K.-H., Ebinghaus, R., Schroeder, W. H., Blanchard, P., Kock, H. H., Steffen, A., et al. (2005). Atmospheric mercury concentrations from several observatory sites in the Northern Hemisphere. Journal of Atmospheric Chemistry, $50,1-24$.

Kim, K.-H., Mishra, V. K., \& Hong, S. (2006). The rapid and continuous monitoring of gaseous elemental mercury (GEM) behavior in ambient air. Atmospheric Environment, 40, 3281-3293.

Kock, H. H., Bieber, E., Ebinghaus, R., Thees, T. G., \& Spain, B. (2005). Comparison of long-term trends and seasonal variations of atmospheric mercury concentrations at the two European coastal monitoring stations Mace Head, Ireland, and Zingst, Germany. Atmospheric Environment, 39, 7549-7556.

Kocman, D., Vreča, P., Fajon, V., \& Horvat, M. (2011). Atmospheric distribution and deposition of mercury in the Idrija $\mathrm{Hg}$ mine region, Slovenia. Environmental Research, 111, 1-9.

Kotnik, J., Horvat, M., \& Dizdarevič, T. (2005). Current and past mercury distribution in air over the Idrija $\mathrm{Hg}$ mine region, Slovenia. Atmospheric Environment, 39, 7570-7579.

Ladle, R. J., Jepson, P., Araújo, M. B., \& Whittaker, R. J. (2004a). Dangers of crying wolf over risk of extinctions. Nature, 428, 799.

Ladle, R.J., Jepson, P., Araújo, M.B., \& Whittaker, R.J. (2004b). Crying wolf on climate change and extinction. School of Geography and the Environment (Oxford University), Selected Publications and Output, Supplemental Publications, http://www.geog.ox.ac.uk/research/biodiversity/output. html\#supplements. Accessed 25 Feb 2013.

Lambertsson, L., \& Matsnilsson, M. (2006). Organic Material: The primary control on mercury methylation and ambient methyl mercury concentrations in estuarine sediments. Environmental Science and Technology, 40, 1822-1829.

Limpert, E., Stahel, W. A., \& Abbot, M. (2001). Log-normal distributions across the sciences: keys and clues. BioScience, 51, 341-352.

Lin, C.-J., \& Pehkonen, S. O. (1999). The chemistry of atmospheric mercury: A review. Atmospheric Environment, 33, 2067-2079.

Lindberg, S. E., \& Stratton, W. J. (1998). Atmospheric mercury speciation: concentrations and behavior of reactive gaseous mercury in ambient air. Environmental Science \& Technology, 32, 49-57.

Lindqvist, O., \& Rodhe, H. (1985). Atmosphere mercury: A review. TELLUS, $37 \mathrm{~B}, 136-159$.

Llanos, W., Higueras, P., Oyarzun, R., Esbrí, J. M., López Berdonces, E. M., García Noguero, A., et al. (2010). The MERSADE (European Union) project: Testing procedures and environmental impact for the safe storage of liquid mercury in the Almadén district, Spain. Science of the Total Environment, 408, 4901-4905.

Loppi, S. (2001). Environmental distribution of mercury and other trace elements in the geothermal area of Bagnore (Mt. Amiata, Italy). Chemosphere, 45, 991-995.

Loredo, J., Ordoñez, A., Gallego, J. R., Baldo, C., \& GarcíaIglesias, J. (1999). Geochemical characterisation of mercury mining spoil heaps in the area of Mieres (Asturias, northern Spain). Journal of Geochemical Exploration, 67, 377-390.

Martínez-Coronado, A., Oyarzun, R., Esbrí, J. M., Llanos, W., \& Higueras, P. (2011). Sampling high to extremely high $\mathrm{Hg}$ concentrations at the Cerco de Almadenejos, Almadén mining district (Spain): The old metallurgical precinct (1794 to $1861 \mathrm{AD}$ ) and surrounding areas. Journal of Geochemical Exploration, 109, 70-77.

Mashyanov, N. R., \& Reshetov, V. V. (1995). Geochemical ecological monitoring using remote sensing technique. Science of the Total Environment, 159, 169-175.

Mercury Policy Project. (2008). U.S. joins EU in banning mercury exports; environmentalists applaud bi-partisan effort. Published on line: October 15th, 2008, http:// mercurypolicy.org/?p=489. Accessed 25 Feb 2013.

Moreno, T., Querol, X., Alastuey, A., García do Santos, S., Fernández Patier, R., Artiñano, B., et al. (2006). PM source apportionment and trace metallic aerosol affinities during atmospheric pollution episodes: a case study from Puertollano, Spain. Journal of Environmental Monitoring, 8, 1060-1068.

Morteani, G., Ruggieri, G., Möller, P., \& Preinfalk, Ch. (2011). Geothermal mineralized scales in the pipe system of the geothermal Piancastagnaio power plant (Mt. Amiata geothermal area): a key to understand the stibnite, cinnabarite and gold mineralization of Tuscany (central Italy). Mineralium Deposita, 46, 197-210.

Myers, G. J., Davidson, P. W., Cox, C., Shamlaye, C., Cernichiari, E., \& Clarkson, T. W. (2000). Twenty-seven years studying the human neurotoxicity of methylmercury exposure. Environmental Research, 83, 275-285.

Ninomiya, T., Ohmori, H., Hashimoto, K., Tsuruta, K., \& Ekino, S. (1995). Expansion of methylmercury poisoning outside of Minamata: an epidemiological study on chronic methylmercury poisoning outside of Minamata. Environmental Research, 70, 47-50.

Nriagu, J., \& Becker, C. (2003). Volcanic emissions of mercury to the atmosphere: Global and regional inventories. Science of the Total Environment, 304, 3-12.

O'Rourke, D., \& Connolly, S. (2003). Just oil? The distribution of environmental and social impacts of oil production and consumption. Annual Review of Environment and Resources, 28, 587-617.

Oyarzun, R., Higueras, P., Esbrí, J. M., \& Pizarro, J. (2007). Mercury in air and plant specimens in herbaria: A pilot study at the MAF Herbarium in Madrid (Spain). Science of the Total Environment, 387, 346-352.

Oyarzun, R., Lillo, J., Sánchez Hernández, J. C., \& Higueras, P. (2005). Pre-industrial metal anomalies in ice cores: A simplified reassessment of windborne soil dust contribution and volcanic activity during the last glaciation. International Geology Review, 47, 1120-1130.

Pacyna, E. G., Pacyna, J. M., Steenhuisen, F., \& Wilson, S. (2006). Global anthropogenic mercury emission inventory for 2000. Atmospheric Environment 40,, 4048-4063.

Pacyna, E. G., Pacyna, J. M., Sundseth, K., Munthe, J., Kindbom, K., Wilson, S., et al. (2010). Global emission of mercury to the atmosphere from anthropogenic sources in 2005 and projections to 2020. Atmospheric Environment, 44, 2487-2499. 
Palinkas, L. A., Mashyanov, N. R., Sholupov, S. E., Durn, G., Miko, S. (1990). Mercury in the atmosphere over rural, urban and industrial parts of Zagreb city. Rudarsko-geolosko-naftni zbornik, 2, 19-27.

Pirrone, N., Aas, W., Cinnirella, S., Ebinghaus, R., Hedgecock, I. M., Pacyna, J., et al. (2013). Toward the next generation of air quality monitoring: Mercury. Atmospheric Environment, 80, 599-611.

Pogarev, S. E., Ryzhov, V. V., Mashyanov, N. R., \& Sobolev, M. B. (1997). Mercury values in urine from inhabitants of St. Petersburg. Water, Air, and Soil Pollution, 97, 193-198.

Pyle, D. M., \& Mather, T. A. (2003). The importance of volcanic emissions for the global atmospheric mercury cycle. Atmospheric Environment, 37, 5115-5124.

Richey, J. E., Devol, A. H., Wofsy, S. C., Victoria, R., \& Riberio, M. N. G. (1988). Biogenic gases and the oxidation and reduction of carbon in Amazon River and floodplain waters. Limnology and Oceanography, 33, 551-561.

Rossini Oliva, S., \& Fernández Espinosa, A. J. (2007). Monitoring of heavy metals in topsoils, atmospheric particles and plant leaves to identify possible contamination sources. Microchemical Journal, 86, 131-139.

Saleem, M., Alfred, S., Bahnisch, R. A., Coates, P., \& Kearney, D. J. (2013). Mercury poisoning from home gold amalgam extraction. The Medical Journal of Australia, 199, 125-127.

Schuster, P. F., Krabbenhoft, D. P., Naftz, D. L., Cecil, L. D., Olson, M. L., Dewild, J. F., et al. (2002). Atmospheric mercury deposition during the last 270 years: a glacial ice core record of natural and anthropogenic sources. Environmental Science and Technology, 36, 2303-2310.

Selin, N. E., et al. (2007). Chemical cycling and deposition of atmospheric mercury: Global constraints from observations. Journal of Geophysics Research D: Atmospheres, 112. Article no. D02308.

Sholupov, S. E., \& Ganeyev, A. A. (1995). Zeeman absorption spectrometry using high frequency modulated light polarization. Spectrochim Acta B, 50, 1227-1238.

Sholupov, S., Pogarev, S., Ryzhov, V., Mashyanov, N., \& Stroganov, A. (2004). Zeeman atomic absorption spectrometer RA-915+ for direct determination of mercury in air and complex matrix samples. Fuel Processing Technology, 85, 473-485.

Sigler, J. M., Mao, H., \& Talbot, R. (2009). Gaseous elemental and reactive mercury in Southern New Hampshire. Atmospheric Chemistry and Physics, 9, 1929-1942.

Sillman, S., Marsik, F., Al-Wali, K.I., Keeler, G.J., \& Landis, M.S., (2005). Models for the formation and transport of reactive mercury: results for Florida, the Northeastern U.S. and the Atlantic Ocean. Fifth Air Quality Conference: Mercury, Trace Elements, $\mathrm{SO}_{3}$ and Particulate Matter, Arlington, VA., September 19-21, 2005, http://wwwpersonal.umich.edu/ sillman/web-publications/SillmanHgAQV05.pdf.

Slemr, F., Brunke, E. G., Ebinghaus, R., \& Kuss, J. (2011). Worldwide trend of atmospheric mercury since 1995. Atmospheric Chemistry and Physics, 11, 4779-4787.

Slemr, F., Brunke, E.-G., Ebinghaus, R., Temme, C., Munthe, J., Wangberg, I., et al. (2003). Worldwide trend of atmospheric mercury since 1977. Geophysical Research Letters, $30,23-31$.
Smith, W. R., Montopoli, G., Byerly, A., Montopoli, M., Harlow, H., \& Wheeler, A. R., I. I. I. (2013). Mercury toxicity in wildland firefighters. Wilderness \& Environmental Medicine, 24, 141-145.

Smith, R. G., Vorwald, A. J., Patil, L. S., \& Mooney, T. F., Jr. (1970). Effects of exposure to mercury in the manufacture of chlorine. The American Industrial Hygiene Association Journal, 31, 687-700.

Spiegel, S. J., \& Veiga, M. M. (2005). Building capacity in small-scale mining communities: Health, ecosystem sustainability, and the Global Mercury Project. EcoHealth, 2, 361-369.

Sprovieri, F., Pirrone, N., Ebinghaus, R., Kock, H., \& Dommergue, A. (2010). A review of worldwide atmospheric mercury measurements. Atmospheric Chemistry and Physics, 10, 8245-8265.

Sunderland, E. M., Krabbenhoft, D. P., Moreau, J. W., Strode, S. A., \& Landing, W. M. (2009). Mercury sources, distribution, and bioavailability in the North Pacific Ocean: Insights from data and models. Global Biogeochem. Cy. 23. Article no. GB2010.

US EPA. (2001). Environmental technology verification report: LUMEX Ltd. mercury continuous emission monitor. U.S. Environmental Protection Agency, http://www.epa.gov/ etv/pubs/01_vr_lumex_cem.pdf.

US EPA. (2007). Mercury Response Guidebook-Section 3. http://www.epa.gov/epaoswer/hazwaste/mercury/pdf/ chapter3.pdf, May 2007.

US OSHA (2007). Health and safety (Hg). Occupational Hazards, http://www.hgtech.com/HSE/HSE.htm. Acceded 25 Feb 2013.

US EPA. (2012). What is a toxic substance? Learn About Chemicals Around Your House, US Environmental Protection Agency, http://www.epa.gov/kidshometour/toxic. htm. Acceded 25 Feb 2013.

Varekamp, J. C., \& Buseck, P. R. (1981). Mercury emissions from Mount St Helens during September 1980. Nature, 293, 555-556.

Vaselli, O., Higueras, P., Nisi, B., Esbrí, J. M., Cabassi, J., Martínez-Coronado, A., et al. (2013). Distribution of Gaseous $\mathrm{Hg}$ in the Mercury Mining District of Mt. Amiata (Central Italy): a Geochemical Survey Prior the Reclamation Project. Environmental Research, 125, 179-187.

Veiga, M. M., Bermudez, D., Pacheco-Ferreira, H., Martins Pedroso, L. R., Gunson, A. J., Berrios, G., et al. (2005). Mercury pollution from artisanal gold mining in Block B, El Callao, Bolívar State, Venezuela. In N. Pirrone \& K. Mahaffey (Eds.), Dynamics of mercury pollution on regional and global scales: atmospheric processes. Human exposure around the world (pp. 421-450). Norwell, Massachusetts: Springer.

WHO. (2000). Air quality guidelines for Europe. WHO Regional Publications European Series 91, World Health Organization Regional Office for Europe, Copenhagen, $288 \mathrm{pp}$.

WHO (2005). Mercury in drinking-water. Background document for development of WHO Guidelines for Drinkingwater Quality, World Health Organization, http://www. who.int/water_sanitation_health/dwq/chemicals/mercury/ en/. Acceded 25 Feb 2013.

Yasutake, A., Cheng, J. P., Kiyono, M., Uraguchi, S., Liu, X., Miura, K., et al. (2011). Rapid monitoring of mercury in air 
from an organic chemical factory in China using a portable mercury analyzer. The Scientific World Journal, 11, 1630-1640.

Yuen, E., Cortez, P. S., \& Goebel, P. J. (2000). Family poisoned by mercury vapor inhalation. The American Journal of Emergency Medicine, 18, 599-602.
Žagar, D., Knap, A., Warwick, J. J., Rajar, R., Horvat, M., \& Četina, M. (2006). Modelling of mercury transport and transformation processes in the Idrijca and Soča river system. Science of the Total Environment, 368, 143-163. 